\title{
FASHION, FASHIONABLE INTELLIGENCE, AND THE VICTORIAN NOVEL: THE VERSATILE CASE OF BLEAK HOUSE
}

\author{
By Sumiao $\mathrm{Li}$
}

\begin{abstract}
ANTI-BLEAK HOUSE
A BLEAK HOUSE that is indeed, where the north winds meet to howl an ignoble concert, and bitter blasts mourn like tortured spirits of rebels . . . where the whirlwind and the hurricane vow their vengeance. . . . Woe to the inhabitant of the Bleak House if he is not armed with the OVERCOAT and a SUIT of FASHIONABLE and substantial Clothing, such as can only be obtained at E. Moses \& Sons Establishments. . . . Who would covet a Bleak House in the month of March, when the old winds take out a fresh license...

- Advertisement for E. Moses \& Son from the Inner Back Cover of the first installment of Bleak House (March 1852) ${ }^{1}$
\end{abstract}

THAT AN ADVERTISEMENT ON fashionable clothing should reference a novel which ostensibly satirizes the world of fashion is not as striking as it seems. It points toward the affinity between clothes/body making and novel/book production, an affinity widely attested to in contemporary literature. An 1836 Court Magazine piece, for instance, puts it like this:

FASHION in books may now be said to fluctuate as frequently as fashion in bonnets, and a monthly commentary on the changes in literary modes, might just as well be circulated as a periodical magazine of fashion in dress. We might express ourselves thus: - "One of the metropolitan publishers has introduced elegant novelties in the way of town prints, produced with small neat plates, judicious gatherings, and a becoming binding ...." ("The Vicissitudes of a Silver Tea-Pot" 68)

For this writer and many others, book production and bonnet making can be talked about in very many of the same terms - modes, novelties, prints, plates - not the least because they are underwritten by the same language, or rather subjected to the same rule, of "FASHION." Fashion - mostly but not always with a capitalized F and tautologically conceived of as that which makes it fashionable - has become such a paradigmatic driving force in modern England that anti-fashion functions as the shortest, most direct route to be in: an advertising strategy deployed by companies like Moses and Son in a rhetoric that makes full use of the fluidity of language to circulate everything back to the magnetic space constituted by polar opposites. 
One might wonder what "BLEAK HOUSE" in the ad refers to. Is it a reader's dwelling place? The monthly number of a serialized novel? The specific house of a specific character in the novel? The actual England in the month of March? The figural England as described in the fiction? The human mind, heart, body, or burial place? Or something else? Theoretically, it is an open sign with virtually infinite referents until and unless the "distinction of the moment" or the "dictator of the hour" - each an erstwhile definition of fashion - calls for some "judicious gatherings," declaring this is that and that this. ${ }^{2}$

And so, what is "ANTI-BLEAK HOUSE"? It is also a floating sign, signifying no more and no less than the multivalent "SUIT", which can be sartorial, legal, personal, or emotional. Similarly, the word "blasts" describing the personified winds can go on endlessly - bittering, vowing, mourning, revenging, rebelling, licensing - until and unless fashion calls for and shouts out a "becoming binding."

While vaguely suggestive of what's to come in the monthly installment, all the black letters on bluish-green paper exist not so much to signify as to create sound and fury in a field of tension constituted by fashion/Bleak House (Dickens's serial was meant to be the rage of the day) and anti-fashion/anti-Bleak House. The goal aimed at is the possibility of being discussed - or rather visibility - which has come to be a quintessential means to the circulation of "fashionable currency," a term made popular by the Silver-Fork School of Fashionable Literature. ${ }^{3}$ In the days of the Great Exhibition (1851), it takes increasingly more for anybody or anything to become the talk of the town, and especially in printed form. In other words, it takes increasingly more to be in fashion rather than out of it, no matter whether Chizzle, Drizzle, Mizzle, or Tangle is in Chancery; no matter whether Cooddle, Doodle, Fooddle, or Mooddle is in government; no matter whether Barbury, Chadband, Jellyby, or Pardiggle is in religion. For by mid-century, that "tyrant" or "goddess" fashion - that unique modern form of power that cannot be named otherwise without losing its distinctive taste - has not only cut through all major bodies of Victorian institutions but also gone inside to shape the Victorian mind, producing what Dickens compares to the "fiend": "fashionable intelligence" (57; ch.2).

What is this fiend? How does it relate to Victorian print culture in general and the realistic novel - such as exemplified by Bleak House - in particular? Surprisingly, questions like these have been ignored by the vigorous and voluminous critical energy flowing to what Lyn Pykett has termed the "Dickens Industry" and other major branches of Victorian studies (1-22). Surprising, because "fashion," "the world of fashion," "fashionable society," "fashionable life," "fashionable intelligence," etc. - as lived realities as well as critical concepts - are so prominently there, rich and dynamic, in Dickens, in Thackeray, in Anthony Trollope, in George Eliot: i.e., in the Victorian consciousness. Surprising, also because the rise of fashion studies in the 1960s and its flourishing from the 1980s on have brought to light various aspects of Victorian fashions. ${ }^{4}$ Yet, other than a few pieces on (sartorial) fashions and specific sides of Victorian culture, ${ }^{5}$ each major turn in Victorian studies - the modern, the material, the psychological/cognitive, to name but a few most relevant to my topic ${ }^{6}-$ while brilliant, has managed to let go untouched what Dickens and his contemporaries felt so poignantly: fashion as a paradigm of modern power; "fashionable intelligence" as a new mode of being and knowing in the modern world; and both as central to what Elaine Freedgood has termed the Victorian "thing culture," central to the Victorian mind/psyche, and, of course, central to their relationship in the emergence of a mass culture of industrial capitalism. 
By retrieving the historical contours of fashion and fashionable intelligence in Victorians' unprecedented experience of a quickly modernizing society, this article explores how they affected the development of the realistic novel like Dickens's. My argument is this: when fashion emerged as a new social, cognitive and emotive power in the nineteenth century and when "fashionable intelligence" rose as a paradigm of modern cognition, they significantly shaped Victorian formal realism by inflecting its four major aspects - characterization, thematic development, narrative structure, and linguistic construction - all toward an urgent concern with what I shall call the "medium function" crystalized by nothing but la mode: la mode that arrests the restless motion of time briefly, shaping it into an attention-holding spatial extension - an object or image - before it abandons such and moves on to catch another moment for architectural construction, real or virtual, or rather real as virtual, as will be elaborated later. Using Bleak House as an example, I shall demonstrate the following: when fashion doubles on intelligence in all its senses, the novel as a literary genre and as just its "well-named" namesake ${ }^{8}$ - the latest mode of "life by time" (Forster qtd. in Watt 22) becomes a fundamental means to a modern virtual reality-dominated life. That is, a mediated life in which a thing has meaning only when, mirrored by fashion, it occupies some virtual space on the other side of the material; or when, in the light of fashion, the thing hollows itself out and metamorphoses into a three-dimensional holder like a vase, vessel, or vehicle that has a hole in it as its fourth dimension - the dimension of time - for future use; in other words, the thing becomes a pure medium like la mode with a piece of vesture, crinoline or otherwise, as its root metaphor. It is an extra-terrestrial life in which characterization and configuration, plotting and narration, theme-building and value creation, all have to go a kind of virtual way: a way in which the center of self and identity, of consciousness and narration, of value and meaning, will be offered - in the name and for the sake of one and oneness - to another yet another entity, perennially, from person to thing and vice versa, again and again: an offer that sets in a dialectical process of progress and regress, possession and loss, prosperity and ruin, sovereignty and isolation. To some extent, then, this project is a review of Raymond Williams's understanding of the Victorian novel as registering a "new kind of consciousness" in response to the "crisis of a knowable community" $(9,16)$. As will be detailed, this "new kind of consciousness" was inevitably mediated by a new force: fashion.

\section{Fashion as a New Form of Power and the Beau Monde as a New Virtual Estate of Modernity}

BY THE EARLY NINETEENTH CENTURY, English people were deeply aware of a "new power of the day."

Ruling the court, the camp, the grove

And maids below and maids above. ("Fashion in 1826" 88)

The New Monthly Magazine's "new power of the day" in 1827 was fashion, whose sway was testified by numberless other sources. For instance, Thomas Gillet, a one-time fashionable writer, said in 1819 that fashion was "the tyrant that most widely reigns" (1). By 1829, Letitia Landon, the poet, was still lamenting "fashion, that tyrant." In 1832 Lady Harriet Pigott framed Britons as "the greatest slaves" to fashion (74), and in 1837 Countess Blessington reiterated the notion: "All here are slaves; yes, positive slaves, and to the most tyrannical of all sovereigns - Fashion" (159). As time wore on, the tyrant was more likely to be called a 
queen or goddess, whose reign, however, was equally tight. An 1848 piece of the London Literary Pioneer would put it like this:

There exists a sovereign goddess, whose most oppressive decrees, even in these revolutionary times, have never met with the slightest opposition; whose edicts none have ventured to gainsay; whose fancies stand for law. . . This queen of autocrats is yclept - FASHION. ("The Rise and Progress of Fashion" 25)

What is this new power called fashion? "What her parentage, or where her home?", so asked the writer Mrs. Stone in 1846 (1). "What are the laws of Fashion, and who made them? Who regulates their absurdities and their proprieties?", thus inquired George A. Sala in 1853 (193). Like them, many other Victorians attempted philosophical, sociological, and/or metaphysical interpretations of the new "potentate." Their myriad comments being impossible to exhaust, I shall simply pull together four major strands that I deem as most relevant to the development of the realistic novel.

\section{Fashion as Sun, Light and Atmosphere}

FASHION IS THE NEW LIGHT or a major source of it in the new world - this is what Dickens suggests by repetitively using, albeit with a satirical tone, the following terms to describe the beau monde or its leaders: "tremendous orb" (705; ch. 48), "the solar system" (ibid), "every dim little star revolving around her" (60; ch. 2); "brilliant and distinguished circle" (203, 207, 210, 212; ch. 12), "Blaze and Sparkle, the jewelers" (60; ch. 2, 842; ch. 58), "Sheen and Gloss the mercers" (ibid), and so on. Expressions like these are part and parcel of a rich Victorian lexicon of fashion widely deployed in contemporary literature. The Court Journal, for instance, is filled with such terms as "the sun of fashion," "the rays of fashion," the sudden "blaze of fashion."

The prevalence and pervasiveness of the light metaphor speaks of a so-far critically neglected fact: nineteenth-century people were conceiving of fashion on a deeper and wider level than we have acknowledged so far. The point can be further illustrated by a poem from an 1848 issue of Le Follet:

Ever changing in fancy, in brilliance, and charms, The loves and the graces I summon to arms From the iris-eyed rainbow, that circles my throne, I scatter the spangles of Venus's zone;

From each sparkling atom new conquests arise, Caprices so charming, that beauty's bright eyes Have a power so resistless, when aided by me, That the world bows in homage to every decree.

The wide earth's my empire! - in Araby's sands In the waves of Ceylon they await my commands In the rose land of Persia - the vales of Cashmere And Lyons and Spitalfields joyfully hear;

The plume from the ostrich - the pearl of the sea The loom's gorgeous fabrics pay homage to me! 
Oh, Children of Labour! - of world honour'd toil!
For you with a breath I create or despoil;
The fancies of FASHION, that change with the hour,
Extend your resources and strengthen your power -
Encourage - enlighten - exalt - sustain -
And the EMPIRE OF FASHION supreme shall remain! ("The Empire of Fashion" 60)

This verse signed by Eliza sets up some intricate cosmic connections: I, the sun of fashion, "scatter the spangles of Venus's zone" to shine over the "wide earth." The realm of fashion extends, not only transnationally from Araby to Ceylon to Spitalfields, but also throughout the universe; and the force of fashion penetrates "each sparkling atom," transforming such solid stuff as sands, land, plume, pearl, and fabrics into a "breath" that can "Encourage - enlighten - exalt - sustain" human life on earth. The dashes in the poem visualize this "breath" and bring attention to places of their absence as where the "breath" may be stronger, where it fully weaves into all the words and all the spaces in between that it becomes invisible, invisible but substantial, soliciting impulsive exclamations in the end!

The "breath" image vividly conveys another nineteenth-century metaphor about fashion: airy nothing. "All that's solid melts into air" - this Marxian appropriation of a Shakespearean conceit has been widely known as a figure for modern disintegration, such as explored by Marshall Berman in his book so named. What is less known, however, is that besides Marx, many other Victorians deployed the figure to portray fashion as a dialectical process between disintegration and consolidation, liquidation and crystallization. For instance, an 1843 Court Journal piece acknowledges fashionable costume and festal meetings as "airy nothings" that paradoxically matter much:

Thus, the outward uniform of fashion rallies, and keeps together the host of the high, the refined, the intellectual. In itself there is nothing; but as an emblem it is much, being one of the few delicate and silvery links that pervade the earth, connecting man with man, in the purer and more graceful phases of his existence. There is much in what men deem but "airy nothings." ("Fashionable Nothings" 9)

The main point here recalls Thomas Carlyle in Sartor Resartus: "Society is founded upon Cloth" and clothes are the "visible emblems" of Man's "invisible bonds to All men" $(45,53)$. Yet whereas Carlyle goes idealistic in seeing a transcendental God or Deity as the invisible link behind all human relations, the advocates of fashion might have something more physical, material, and secular in mind when they talk about the "breath" or "airy nothings" of fashion as "one of the few delicate and silvery links that pervade the earth, connecting man with man": i.e., streaks of airy blue or the ethereal atmosphere of a planet or star as root metaphors for fashion. When each fashionable is said to fancy "her own orbit the only course traced through the atmosphere of FASHION" ("Where is the Fashion" 114) this atmosphere is no longer Carlyle's metaphysical "Void deep" that nullifies unless it is animated by God and turns into the "ether of Deity" $(46,48)$. Instead, this ethereal thing permeates, connects, and sustains, functioning simultaneously as environment, medium and energy for both the animate and the inanimate. Where fashion prevails, a new cosmology is flowing even as it might not be consciously registered or practiced. One in which the metaphysical, instead of transcendental, doubles on the physical world. One in which human beings have a new way of relating to objects and to each other, a new way of knowing and being known, a new way 
of occupying time and space; for virtually everything now has to be pulsed through by the breath or atmosphere of fashion, seen in its light, or mirrored by it.

\title{
2. The Mirror or Glass of Fashion
}

FROM THE TIMES 1789 "Mirror of Fashion" reporting on the movements of the fashionable world through La Belle Assemblée and other periodicals' similarly named columns showcasing the latest modes in dress and accessories to the fin-de-siècle Hearth and Home's "Glass of Fashion" presenting gowns and gossips, the mirror or glass as an image or a real piece of furniture was tightly tied to fashion and became another of its root metaphors. Being the "glass of fashion, and the mould of form; and the observed of all observers" was one of the most flattering epithets a person or thing could enjoy in the nineteenth century. ${ }^{10}$

The pervasiveness of fashion as mirror suggests the emergence of a new cognitive, emotive and ontological model different from the traditional paradigm conveyed by the "discourse of the soul," which in Rick Rylance's opinion was still largely valid via faculty psychology's 'default position' in nineteenth-century psychology (27). As elaborated by Rylance, this discourse "disconnected mind from its earthly origins and structured its ontology, as it were, from above" (27). In this vertically stretched mode, the mind or the soul was "unlocated" and, unlike such "lower faculties" as feeling, desire and appetite, was "exempted from material determination" (Rylance 27). In the new fashion-driven model, however, me, myself, my mind, my soul, my self-awareness, my aspirations, my longings, as well as my objects, are all to be found in the horizontally-stretched, materially-mediated virtual world. Like Aesop's dog looking into a stream, a modern being cannot see or want his or her meaty object - including the body into which the mind/soul has descended - unless it is mirrored by the glass of fashion - a phenomenon of "shadow hunting" in the words of a Court Journal contributor ("Shadow Hunting" 2). The fashion-mirrored virtual space is where the meaty object stops being an earthly and earthy heap of opaque matter but becomes shiny and sparkly; and like airy, fairy particles of the realm of light and mystery, it solicits view, knowledge, desire and attention - rare resources always on the verge of being engulfed by oblivion, ennui, boredom and vortexes of choices. If person and thing are lucky to stay long enough in the vicinity of fashion, they themselves might just turn into crystal mirrors with new virtual spaces opened up in them for themselves and those close to them, so on and so forth until all beings under the areal sky-mirror are virtually connected, having a dual existence in this world of physicality and that of virtual reality.

That the mirror of fashion does not simply reflect but transfigures - magically - is testified by numerous contemporary documents. For instance, the following Court Journal poem makes a typical point of the magical power of fashion to transform:

\author{
Enchanting Fashion! Tell me which \\ Art thou, a will-o'-wisp, or witch, \\ Or one of those delightful things \\ That poets deck with stars and wings \\ Sent down with brilliant spell and wand, \\ To turn the earth to fairy land. ("The Court Day" 8)
}

Here, fashion comes close to what Gilles Lipovetsky has recently termed the "system of aesthetic fantasy" which might be rooted in the human hunger for and attempt at 


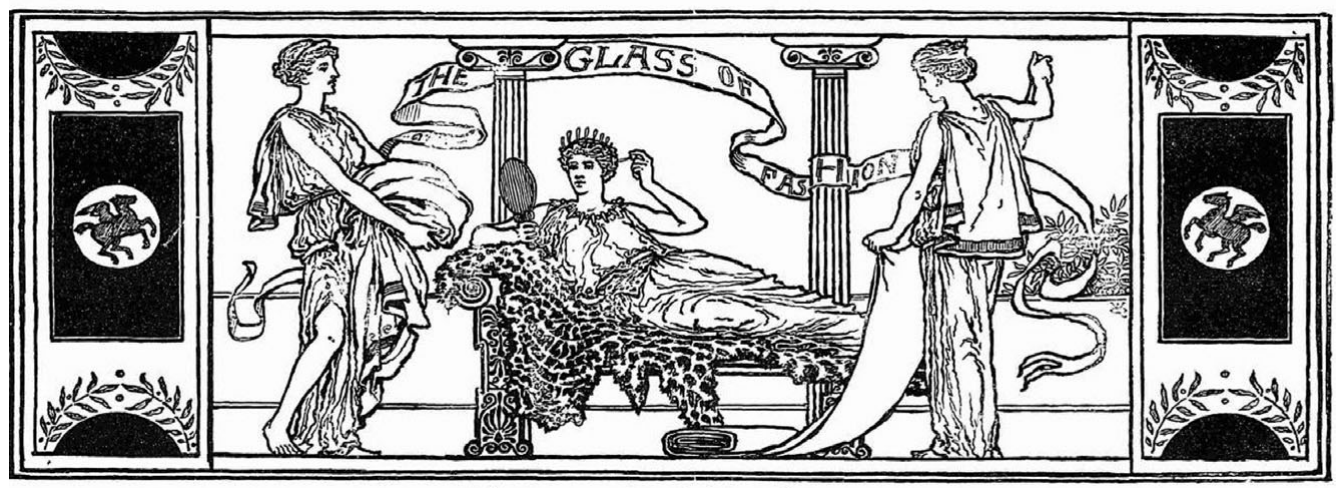

Figure 1. "The Glass of Fashion,” Illustration from Hearth and Home 1 (21 May 1891): 26.

beauty, creation, fancy and imagination (25), but which always goes with some miraculous combination of anonymous factors, some mythic materialization of cosmic forces - both social and natural - in local circumstances: fashion as mirror is human effort decked by "stars and wings."

With such a mirror, there arises a new dynamic between the inside and the outside. While the glass of fashion is nothing but a smooth and brilliant surface, its superficiality nonetheless projects an unfathomable depth. As the mirror minds nothing but external radiance, it inevitably opens up a remarkable interior, an immense virtual space that can be boundless depending on where the mirror is. As shown in the Hearth and Home illustration (Figure 1), the virtual space extending in the mirror in front of the centered and foregrounded fashionable lady's face would be the whole sky-space marked by local trees and Corinthian colonnades - the landscape of human society where modern beings hold up a piece of shiny material or some dragon-like fabric or one another as the glass of fashion so that the outside flows seamlessly into the inside and vice versa; where the atmospheric tissue of fashion goes into and materializes as now tree leaves, now darkness of night and its mares, now human body and its costume, now fashionable lioness and headdress, now clothes and dragon-like fabric again. There might be loose ends but no discontinuity in the cosmic flow of fashion as a dialectical exchange between time and space.

\section{Fashion as a Dialectical Exchange between Space/Rest and Time/Motion}

WHILE AN 1823 NEW Monthly Magazine contributor declared fashion to be the "Cynthia of the minute" ("Philosophy of Fashion" 238), by 1846 Mrs. Stone still felt the need to recall Horace Walpole for a similar idea: "Isn't fashion 'a persuasion that nothing was ever right till the present moment, and that the present moment will immediately be as wrong as all its predecessors?"' (11). Nineteenth-century people's meditation on fashion as time with regard to an accelerated pursuit of novelty bespeaks their intuition into what Walter Benjamin decades later would frame as the "dialectical image" in several different senses.

First, fashion embodies a dialectic between rest and motion, between change and its arrest. The quotes above and far more - such as the "tide of fashion," the "fickleness of fashion," the "chameleon fashion," the "changeful deity," the "locomotive fashion" - 
suggest that fashion means change and, like Bergson's time or la durée, is pure mobility. Yet, paradoxically, fashion is also mobility's rest mode, providing a major means to anchoring modern beings' existential uncertainty and spiritual restlessness. In terms of the tide metaphor, fashion is both the ceaseless multidirectional heterogeneous flow that often remains unnamed and unrecognized but also those standstill moments when the tide enters, peaks, and rests seemingly forever in particular situations. It is often those standstills - however ephemeral - that are visible, distinguishable, emotionally and cognitively provoking, and thus give a name to the tide: the fashion for the time being in a dual sense; the fashion of the moment, or the fashion for that ontological tissue - time as being and being time.

The fashion for the time being, then, vividly fleshes out another dialectical image: fashion as a constant exchange between time and space. The ethereal multidirectional shapeless flow of fashion is that of a generative time. For such a time, human beings cannot but be in rather than outside of it as a transcendental spirit. From inside, human beings do try to shape the flow. What with human deliberation and the anonymous forces - including the unconscious part of human efforts - in a specific situation, the shapeless flow of time may turn into a specific spatial extension: a latest pattern of cloth, a new image of the fashionable, a fine point of an argument in the form of a book - in short, an example of the "momentary figures" explored by Sue Zemka in her 2012 book (13). For this latest product to remain in the flow it must have the fourth dimension of emptiness for future occupation, materialization or construction which would connect it back to the general shapeless flow of time.

That the generative time is "maximally tensed toward the future" brings out yet another sense of fashion as a dialectical image (Bakhtin 242): "the new (the pedant) is always the eternally selfsame" (Benjamin, Arcades 548). Each trivia of fashion is in fact an "odd jumble of contradictions, of sympathies and antipathies" (Hazlitt 148). In Benjamin's understanding, the latest novelty of fashion does not just "quote" from its recent predecessors but also from "a more distant ur-past," thus containing the "dream images", the imagination of the collective unconscious set in them (Benjamin as interpreted by Buck-Morss 116, 126, 261). These "dream images" are for Benjamin the "same" that constantly return, unanalyzed and unspecified, to each new mode in similar or different forms. In Ernst Bloch's terms, they might be the "not-yet-conscious" - "a content of consciousness which has not yet become wholly manifest, and is still dawning from the future" (1.116). Although fashion only bespeaks the present, it aligns, I would say, both the past and the future in the current. In fact, the time of fashion - that atmospheric "breath," that cosmic force stemming from some miraculous interactions among stars and planets to "scatter the spangles of Venus" on Earth - is an "all-encompassing present, a constantly burgeoning forth that includes everything we think of as past and future," to quote David Hinton's characterization of the Chinese conception of $q i$, which he translates as "the universal breath-force" $(92,90)$. $Q i$ is a perfect image of fashion as time turning into spatial extensions that mark out its rhythm towards the future, which is forever receding into the past - the past as the perennial movement of $q i$ since the Chinese folklore Deity Pan-Gu created everything from his own body, for instance. It feels a bit uncanny that an 1855 article in Household Words translated Pan-Gu (spelled as "Pwankoo" in the article) as "basined-antiquity" (Milne 68). Time basined in a three-dimensional container will move forward like ethereal breath and transform into other spatial extensions that will soon drop into the baseless fabric again. Time, space, space, time - constant transformation between them is fashion in a general metaphysical sense for sure, but also in a narrow historical sense as it metamorphoses into a new self-reflexive sartorial-symbolic system in the nineteenth century. 


\section{Fashion as a Self-Reflexive Sartorial-Symbolic System}

"FASHION IS FASHION." THIS frequently repeated saying in the nineteenth century succinctly brings out its self-referential, self-constitutive, self-perpetuating characteristic. No matter how many metaphors it dons, fashion can only be fully captured by its own name, and it always refers back to itself as the only and final source of authority, judgement, recognition, and meaning.

This self-reflexivity of fashion was confirmed by the German prince Pükler-Muskau a one-time favorite of English fashionable society - according to whom fashion in England was not "influenced by rank, still less by riches but [found] the possibility of its maintenance only in this national foible [of believing in fashion]" (34). Antedating Roland Barthes by more than a hundred years, the German prince realized the circuitous nature of fashion; he saw that fashion was a "normative whole" which could contain only one variation: "Fashion/unfashionable" (Barthes, The Fashion System 23). In other words, "Fashion is defined by the infinite variation of a single tautology"; it has a "stable form and unstable content" like "the ship Argo, of which each piece is gradually replaced, which nonetheless remained Argo" (288).

As such, fashion is fundamentally different from the old sartorial symbolic mechanism. As discussed implicitly or explicitly by scholars ranging from Habermas to David Kuchta, the old sartorial symbolic mechanism featured the display of the manorial lord; ${ }^{11}$ at its center was the aristocratic body functioning as a theatre of display, sumptuary and otherwise. ${ }^{12}$ In this symbolic system, the crown and its court used material and linguistic signs such as insignia, dress, demeanor, and rhetoric to indicate their naturally/divinely given high status and ruling positions. The public/private division was not relevant because things, including abstract virtues, had to be publicly represented to have meaning. While this system of representation had to have a crowd of spectators before whom it took effect, the crowd itself, usually constituted by dependents, neighbors and tenants, was excluded from the representation and did not have much bearing on it. The crown and its court decided fashion via sumptuary laws, the patronage of art, religious ceremonies and other means.

Different from the old sartorial-symbolic mechanism, the modern system of fashion stars a body which, emptied of traditional trappings like gender and class, is forever on the verge of becoming fashionable. Neither lord nor lady, neither aristocratic nor bourgeois, it can be embodied for the time being by either, by both, by an "odd jumble" of the myriad "antipathies" in life; yet its sole aim and name is just that: the fashionable. In the new symbolic frame, material and linguistic signs no longer indicate but produce the social status of their users. Whoever are able to manipulate the latest set of signs get the distinction; and competition is horizontally - rather than vertically - stretched: one competes with one's equals, i.e. other fashionables, for leading the world as opposed to one's social inferiors who are by definition already failures.

While one might say this system of value exists as long as a society has some minimal commercial development, various scholars have demonstrated that it could not have been influential earlier than 1700. Fernand Braudel, for example, highlights the turn of the eighteenth century as a watershed: "One cannot really talk of fashion becoming all powerful before about 1700. From then on fashion in the modern sense began to influence everything" (316). Like Braudel, Grant McCracken also thinks that the new system of fashion in which things were valued not for their patina but for their fashionability occurred in the eighteenth century (1.31-43). Neil McKendrick likewise regards the late eighteenth and early nineteenth 
centuries as the point when modern fashion truly triumphed over the old symbolic system. Although a triumph-over does not mean a full eradication of the old, or a cessation of the intricate twining of the old and the new - which was indeed widely seen in the early nineteenth century - it does say that fashion was strong enough then to make the Beau Monde feel like a new virtual estate of modernity.

As early as 1806, a La Belle Assemblée author started to talk about the beau monde as a "New World":

The New World ... is called the Beau Monde, or Fine World . . [by which] we do not mean the world itself but the inhabitants of this world... . The Beau Monde, like Swift's Island of Laputa, is for ever changing its place. It is now at London, now at Bath, now at Bristol, now at Brighton: wherever the Emperor is, say the Civilians, there is Rome; wherever fashion resides, there is the Beau Monde. ("The Beau Monde" 5)

Here, fashion and the beau monde double on each other: fashion is what rules the beau monde, which in turn is tautologically perceived to be the people whom fashion has brought together. This circularity brings out a most salient feature of the beau monde in the nineteenth century: it was an extraterrestrial virtual world. Virtual as what the term would suggest to us post-human netizens: it was always mediated by some hard base - a disk, an island, a thing - but it never fully coincided with the "hardware" and was bound to move away to the next base as soon as it arrived, or rather was arriving - since it never fully arrived - at this hard core. The beau monde could be anywhere "fashion resides" and yet not fixed at any one site. It was, "like Swift's island of Laputa, for ever changing its place."

Similarly, virtual were all other aspects of the beau monde as well. Its size, for instance, would better be measured virtually. There might have been "two thousand persons, called the world" ("The Influence of Example in the Fashionable World" 213). There might have been "three thousand" people assembled at a grand ball of fashion at the Opera House in 1837 ("The Grand Ball at the Opera" 337). There might have been the "twice ten thousand for whom earth was made" ("The World of London: Second Series: Part I" 72). The very existence of these different numbers attested to a key paradoxical nature of the beau monde: it was an open exclusive community that could not be measured numerically. Exclusive because, for the time being, it must be limited to a small coterie; once it was accessible to the general public, it stopped being the fashionable world. Yet it was also a community theoretically open to anyone, for who knew what or whom the capricious fashion would favor this moment or next. The beau monde was virtual also in a literal sense: it was fully mediated and substantially made by the expanded and expanding nineteenth-century press. This is an important point I will elaborate on in the next section; suffice it here to say that extensive media representation turned the beau monde into largely a virtual world running in the folds of papers.

All the virtual qualities, greatly enhanced by the early nineteenth century, distinguished the beau monde from the high society of ancien regime, rendering it a miniature and experimental form of modern consumer society. No doubt, some aristocratic values were carried on to nineteenth-century fashionable society; no doubt, landed nobility still dominated it at least for the first half of the century; and no doubt, it was still confused with aristocratic high society in some people's mind. Yet in nature and by definition, it was a new and discrete social institution. Nineteenth-century people were quick to recognize the discreteness of the refreshed virtual world of fashion. One author described it as "that fourth estate of the realm" 
("Sketches of Real Life: No. I" 8); another termed it "this fourth estate of the body politic" ("Where is the Fashion?" 113); yet another claimed that the beau monde was a new caste of "nobility created neither by patent nor by writ, but whose titles are nevertheless acknowledged by general assent" ("The Omnipotence of Fashion" 3).

It was just in responding to, representing and also creating this virtual, largely unknowable community that Dickens's "fiend" - "fashionable intelligence" - was burgeoning forth as a new paradigm of cognition in Victorian England.

\section{Fashionable Intelligence as a Paradigm of Modern Cognition}

LITERALLY AND NARROWLY SPEAKING, "fashionable intelligence" was a brief report on the movements of the beau monde, with its first example traced back to the Times's 1789 eponymous piece, at least. Stemming from "Court News" and "Births, Marriages and Deaths" in early newspapers, "fashionable intelligence" became a distinctive, discrete cultural realm parallel to, if not always subsuming its predecessors by the 1820 s and 30 s, when myriad versions of the column of fashion were mushrooming together with the great transformations print culture was undergoing then. ${ }^{13}$

In tune with the growth of the column of fashion, "fashionable intelligence" got greatly expanded in the early Victorian period. While the range of periodicals it occurred in was widened, the frequency it turned up in a periodical was also increased, as was the actual length of each piece. Moreover, there arose tons of derivatives, such as "Court and Fashion," "Fashionable Arrivals," and "Fashionable Gaieties of the Week." Meanwhile, it also got pictorialized, integrating pictures into its own space, or putting in its vicinity such visual representations as the copperplate prints of the "Galaxy Gallery of British Beauty" mentioned in Bleak House (340; ch. 20).

The expanded "fashionable intelligence" was often used as a selling point by various papers. For example, the Court Journal in the 1850 s frequently gave priority to "fashionable intelligence" in its self-advertising pieces. A typical one runs as follows:

The Court Journal of this day will contain all the fashionable intelligence of London, Paris and the Continental Courts, with the literature, fine arts, the musical review and chit chat, and miscellaneous news of the week; also original articles by distinguished writers. (Times 10)

The increased spotlight time of "fashionable intelligence" as a column enhanced the use of the term in a more general sense.

Broadly speaking, "fashionable intelligence" crystalized the idea of news or information on fashion and the fashionable world. In this sense, "fashionable intelligence" should cover the column of fashion per se and its innumerable derivatives like "Fashions for January" or any other month, "Epistles of Ton," "London Letters," "Brighton News," "Paris Fashions," etc. It should also include a considerable number of essays/poems on fashion that made into even the more conservative periodicals like Blackwood's Edinburgh Magazine. In fact, almost all printed materials from the classified ads to the Silver-Fork School of novels and domestic fiction conveyed some sort of news or information on fashion and the beau monde and were thus special forms of fashionable intelligence. Finally, fashionable intelligence was also the "bon mots" or "on-dits" as they moved around in fashionable parties or periodicals. In short, fashionable intelligence was the talk of the town both in and out of the press. 
As the word of fashion circulated pervasively in and out of the press, fashionable intelligence meant no longer just news or information but the sparks of intellect from that distinctively human faculty which had got a new name by the 1820s: the "fashionable mind" as used in the following: "is Lady B__ dying to know what impression her last night's entertainment had on the fashionable mind, the Morning Post will inform her" (Ellen 219).While the "fashionable mind" could not but see "every aspect of life through the looking-glass of fashion" (Fraser 145), this glass was increasingly equated with the press. ${ }^{14}$ Society hostesses were so eager to have their parties reported under "fashionable intelligence" that it seemed as if they had organized social gatherings just for that purpose. Meanwhile, fashionable guests also attached great importance to being so registered. Merely being in the world of fashion no longer felt enough; one needed the medium of print to authenticate one's fashionable existence. Major Pendennis in Thackeray's The History of Pendennis, for example, read "fashionable intelligence" specifically to see that his name was "down among the guests at my Lord So-and-so's fête" (3). Thackeray himself wanted to have his name printed in the Morning Post's column of fashionable intelligence. Once at the Marquis of Lansdowne's, Thackeray carefully pronounced his name to the newsman Mr. Forster, who, however, deliberately skipped it because Thackeray had attacked fashionable reporters in the Punch serial "Jenkins" (qtd. in Spielmann 319-20). To be "Morning-Posted", as the fashionable slang went, or not to be "Morning-Posted" - that was the question.

The Thackeray-Foster anecdote vividly attested to the emergence of a new mediated life in which the medium per se - the printing press - doubled on fashion to model a new paradigm of modern cognition. Captured most vividly in "fashionable intelligence" as a printed column, this new paradigm had the following characteristics, to say the least.

\section{Embracing the Virtual as the Real}

One remarkable feature of "fashionable intelligence" in its many shapes is its seemingly realistic recording of the ordinary, everyday life of the fashionable, be it the queen, the prince, or some Mr. or Mrs. Fashion. Take for example these pieces from the Morning Post:

The Queen and Prince Albert walked yesterday in the garden of Buckingham Palace.

His Royal Highness Prince Albert rode out on horseback yesterday morning, attended by his Equerry in Waiting. ("The Fashionable World" 5)

Later in the evening, the Countess of Jersey was "at home" to a select circle of the haut ton, about 250 personages of distinction assembling on the occasion... [half-page long list of names.] ("Fashionable Entertainments" 5)

What one sees in these examples are everywhere else in "fashionable intelligence": instead of focusing on major political debates or life-death decisions the VIPs are making, it simply registers the mundane aspects of their life - walking and talking in the park, eating and drinking "at home." Its special focus helps make a new sense of the real. First, the real isn't really the everyday, the mundane; it is the mundane mediated by the press: chosen and designated by the Post as the fashionable, the mundane shines in the light of fashion with the glory of visibility and becomes desirable as the mirror of fashion. Second, the real is always out there virtually in the "fashionable world" as delineated by the press, a world where the 
reader can hope to enter one day, or to enter anew another day - if one is already listed - since the fashionable world changes its location, constitution and so on from day to day. Finally, the real real - the black letters on white paper - is only real because it opens up and connects readers to a vast virtual realm of the queen and the noble, of brilliance and distinction, of splendor and plenty. Thus a shabby genteel like Tony Jobbling in Bleak House can lead his shabby life in a shabby rented room as if it were part of that vast virtual realm. This virtual realm can double on what Benedict Anderson would call the "imagined community" of the nation for sure, but also goes beyond it; for the realm of fashion extends throughout the cosmos, with a landscape that is sky-wide and marked by "meteors" and the "Galaxy," etc.:

But, fashion is Mr Weevle's, as it was Tony Joblings' weakness. To borrow yesterday's paper from the Sol's Arms of an evening, and read about the brilliant and distinguished meteors that are shooting across the fashionable sky in every direction, is unspeakable consolation to him. . . To be informed what the Galaxy Gallery of British Beauty is about . . . and what Galaxy rumours are in circulation, is to become acquainted with the most glorious destinies of mankind. Mr Weevle reverts from this intelligence, to the Galaxy portraits implicated; and seems to know the originals, and to be known of them. (340; ch. 20)

In spite of Dickens's satirical tone, he accurately grasps the role of "fashionable intelligence" in creating a new community imagined on a cosmic level. Via a single sleight of hand, "fashionable intelligence" has dethroned the noble from their supposedly divine-given pedestals, rendering them common human beings subjected to rumors, falls and deaths; and yet by uploading them into the fashionable medium of the press, it has re-created this new realm of the real as an arena of fantasy and fashion.

In this new light of the real as virtual, to read, write, or learn means quite a different thing from the perusal of a biblical text for God's words, truths and revelations; and "fashionable intelligence" once again both represents and creates this new cognitive change.

\section{Cognition as a Self-Fulfilling Process in the Dialectical Exchange Between Space/Rest and Time/Motion}

Once the real starts to be uploaded as the virtual, to read, write or learn are all oriented towards how fashion as actual spatial extensions can best be transformed into virtual space and then back into fashion as time, or vice versa, via the medium of the printing press.

Numberless sources record how a man of fashion begins his day by lolling on a sofa to skim the newspaper and curse it "if he does not find in it a paragraph which he sent to the agent of a fashionable newspaper, generally the Morning Post . . containing an account of his having dined at some titled man's table the day before" ("The World of London: Second Series: Part I" 78). Here, to read is to quickly dive in the actual and virtual sea of words to fish for what one has expected to be there since one has done everything to ensure that it would be there: dining with the right person, writing the experience up in a paragraph to send to the right agent, and rising up at noon to position oneself on the sofa to check its occurrence; after all these ritualistic activities, his presence or absence on paper is bound to shape up or shape down his actual day which must end in another paragraph to be "Morning-Posted." The evening passage is the last effort to recollect the transitory day that can never be marked out enough with fashionable spatial arrangements - clubbing, parading, partying, dining, opera 
going - in yet another spatial maneuvering; for the printed lines on paper, are more likely to bring back the vanished day into the breaths of one's contemporaries, and, via the appeal of a more durable medium than the human flesh, into the breaths of late comers. Underneath a man of fashion's seemingly ludicrous obsession with "fashionable intelligence" is the fashionable mind's serious concern to find the best medium to shape the ethereal shapeless "breath" of fashion as time into more tangible extensions of fashion as space, both real and virtual, captured so well by the folds of newspaper or other media products.

The same concern with the mediated exchange between fashion as time/motion and fashion as space/rest occurs also with two derivatives of "fashionable intelligence" as listed below:

\section{FASHIONABLE ARRIVALS.}

Hon. John Coventry, at Miller's Hotel, from his seat near Windsor.

....

John Lynam, Esq. at ditto, from Ireland.

DEPARTURES.

The Rev. S. R. Hamilton and family, from Miller's Hotel to Cheltenham.

The Hon. John King, from ditto to Paris. (The Morning Chronicle)

That departures and arrivals - instead of the actual trip - should become the foci of the light of fashion seems to confirm Georg Simmel's observation that in modernity, the "accentuation of the stimuli shifts increasingly from its [change's] substantial center to its beginning and end" (qtd. in Lehmann 180). Maybe, but there is also the emergence of a cognitive model that is more bent on marking out boundaries because it is more aware of the lack of any substantial center to change, to trip as change, to the return of the same ethereal flow at home and abroad. What departures and arrivals share are brief standstill moments of rest in an actual place; what the printed "Departures" and "Arrivals" share are attempts to fashion out of the levelling river of oblivion some media products that partially arrest the eternal flow, and basin or box it for future release.

In this perpetual transformation, the fashionable mind anticipates the associations its day or night is going to make in tune with memory and hope already mediated by fashion, guides their actual making with the same, and finally secures them in the virtual room of the fashion-driven printing media. Via the "Tripod of Fashion" ("The Season" 33) - anticipation, association and memory - cognition metamorphoses into a self-fulfilling process in which the subject moves to double on the object in a different time-space, only to start a new series. Seriality - to appropriate Anderson's term again - is the track the modern peripatetic subject takes as it unfolds in the "imagined community" - both bound and unbound by fashion. ${ }^{15}$

\section{Peripatetic Vision Captured and Released in Seriality}

THAT “FASHIONABLE INTELLIGENCE" DONS a peripatetic eye in a peripatetic body is already suggested in the quick tempo in which "Fashionable Arrivals" and "Departures" are made and registered, but it is also most visibly seen in "Fashionable Entertainments," for instance:

On Saturday night there were small parties at the houses of Lady Canning and Lady Frances Leveson, on Sunday, a petite réunion at Lady Salisbury's, and on Monday the week was brilliantly opened by a juvenile fête at Ashburnham House, in honour of Princess Lieven's youngest son. . . On Wednesday 
night Mrs. Scott Murray gave her second ball for the season; and Mrs. Gally Knight had a numerous assembly. ... ("Fashionable Gaieties of the Week" 214-15)

The eye/mind - which seems merely to record but actually names, and by naming brings into distinction these "Gaieties" - keeps moving from day to day with new excitement, which is also a movement across space from one grand house to another. The fashionable eye/mind is not just a transparent mirror, but a vehicle of elsewhere, an empty opening that shifts to take in, like a camera, each occasion of fashion as it arises.

The place from which the fashionable eye/mind sees and reports cannot be captured exactly by the word "transcendental." The point can be further illustrated by the following:

\footnotetext{
Although the season for the balls has not yet been officially announced, we have been privileged to view some charming toilettes, for petites soireés, where the character of les modes for the season might be carefully discerned. ("La Mode" 1)
}

The vantage point of the fashionable eye is the extraterrestrial place the beau monde has reached ahead of society in general. Being immersed in the world of that extraterrestrial place, the fashionable eye/mind is a sensory one in a sensory body that enjoys the "more than usually brilliant" gaieties fashionable gatherings can offer, and it does not hide but instead flaunts his "privilege" of having this vantage point, from which he can confidently pose and reflect all the gaieties with supposedly mirror-clarity for those absent. Those absent, which can be the whole national or international readership of the periodical, might not be in that extraterrestrial place yet, but they are not exactly terrestrial plebeians, either; for they are already part of the fashionable world as "fashionable readers" who can download from the periodical the mediated virtual into their life as the real - the real dream life of phantasmagoria accessible in the "imagined community" they share with the beau monde - not the least because they have the "desire for the real" as Audrey Jaffe would say (119 ), or the "longing for a true presence" as Habermas would characterize modernity (qtd. in Lehmann 160).

For the real-virtual-real transformation to happen as smoothly as possible, the mirrorclarity of the fashionable eye/mind is not enough. It must develop and help others develop what Gillizes Lipovetsky would call the "critical gaze of the worldly-wise" - that modern faculty of "observing each other ["one's peers"] endlessly, appreciating each other's looks, evaluating nuances of cut, color, and pattern in dress" to generate "aesthetic and social judgement" (29). While Lipovetsky sees fashion in general and sartorial fashion in particular as the apparatus for the development of this gaze, it is arguable that various forms of "fashionable intelligence" and especially the column of fashion's monthly statement model such a gaze and might have enhanced the same in the modern reader. Take for example, this one from Le Follet's "La Mode":

\footnotetext{
Ball dresses have made their debut, and their variety in style and material renders it somewhat difficult to make a selection that shall not encroach upon the limits of our paper. . . The front of the body is ornamented with an echellé of flowers, formed with diamonds and artificial fuchsias. The coiffure is a wreath of fuchsias, mixed with foliage of diamonds, descending slightly on the forehead, and falling on each side over the bandeaux.
} 
Another of these toilettes is of white tulle ...

Another toilette of white tulle had the upper skirt trimmed in festoons . . .

We have also observed ...

....

We have seen one in pink. ... (1-2)

The "worldly wise gaze" for minute details, for seemingly infinite differentiation, for nuanced classification and analysis - performed on and for one's peers - emerges full-grown from such fashion writing and fleshes out some unprecedented characteristics of modern cognition.

Yet, the real wisdom of the "worldly wise gaze" lies as much in imagining differences as in creating a new sense of wholeness. For what the fashionable eye/mind aims ultimately is to grab a moment in fashion as time's eternal - let's say, horizontal - flow, a moment like the debut of ball dresses, and turn it into a fully-fledged drop of the universe along a different direction - let's say vertical (the absolute is the opposition while the directions are relative). For this drop to feel real, it must contain as many as possible different species of objects: dinner dresses, soiree costumes, park-parade outfits; and each species must have as many varieties as possible until the moment of being is expanded virtually as high, as wide, as far, as thick, as deep as the universe itself. Thus, fashion's horizontally stretched seriality of the "repetition of a single tautology" is temporarily bound and released in a vertically-oriented seriality of heterogeneity, difference and difference making, which nonetheless is a virtual whole in which the fashionable eye/mind can be lulled into sleep, comfortably massaged by the sense and sensation of "potency." 16 Sleep and dream until there is the need to dive in and fish for what one wants; sleep and dream until one day the ambience of wholeness somehow collapses, and all the objects that have shone in their respective places designated by fashion stop feeling or looking like members of a community but instead dwindle into dull grains of sand on no man's land. The vertically-stretched seriality has come to its end. While the fashionable eye/mind flies away for a new target, the moment of being - the drop of the universe - splashes into the chaotic mass, with not all its former parts being able to go into the next seriality. As ruins or what Zygmunt Bauman calls the "wasted people" and "wasted materials," they will remain in desertion and forlornness, for some time at least, as tangible signs of the paradoxical nature of fashion's wavy and cyclical seriality: it is both progress and regress, moving between prosperity and ruin, a dialectical process which is from its inception sexualized, but not in ways commonly acknowledged.

\section{The Sex of the Fashionable Eye}

LA MODE AND THE Beau Monde. One feminine and one masculine in their etymological roots and in their still current face values. Yet both are fashion and fashion is both. As the new God and Goddess, fashion is "a dual power, Rest and Motion, the one female, and named Yin, - the other male, and named Yang," to appropriate the language of the Household Words (Milne 67). Fashion as an ethereal cosmic force in its brilliant form of light, or in its unbound series - i.e., in its mobility like time and as time - is masculine. Fashion in its rest mode, in its tendency to consolidate into dialectical images, into boxed or "basined" times as spatial extensions - i.e., in its bound serialities - is feminine. In other words, fashion in its restless, ruthless, relentless releasing mode is masculine and in its soft, touchy, feely binding mode is 
feminine. Yet as its binding is also releasing in both kinds of seriality - in the horizontal one, the recurrence of the same name fashion binds its potentially endless release in time while in the vertical the limitation of the moment binds its potentially endless release in naming and differentiating - fashion is simultaneously masculine and feminine. And because mobility in its absolute state feels like stillness, what is masculine is also feminine and vice versa. Fashion only takes sexual difference as the root metaphor for its fundamental modes of mobility; it is not tied to any sex, nor to the human kind only; there are men of fashion, women of fashion, but even more things of fashion.

What is true of fashion is also true of the fashionable eye, mind or vision. When the fashionable eye dissects the body for nuanced differentiation, analysis or simply enjoyment, it is the detached masculine gaze ravishing the feminine body. When it is caught - willingly or involuntarily - in the midst of robes and ribbons, bows and bonnets, and sleeps and dreams in there, it is the feminine gaze immanent in the body. From the mid-century on, Le Follet features a series of narrative poems on fashion and clothing signed by Eurymachus. This mythological figure, now a modern man of fashion, moves freely in the beau monde as a harbinger of its messages to the rest of the world, and yet he frequently drops into sleep or trance in the midst of gaiety-boredom and re-emerges in his scin laeca - the body of light - as his lover Augusta Camperdown. The woman figure would converse with the man still in sleep/trance:

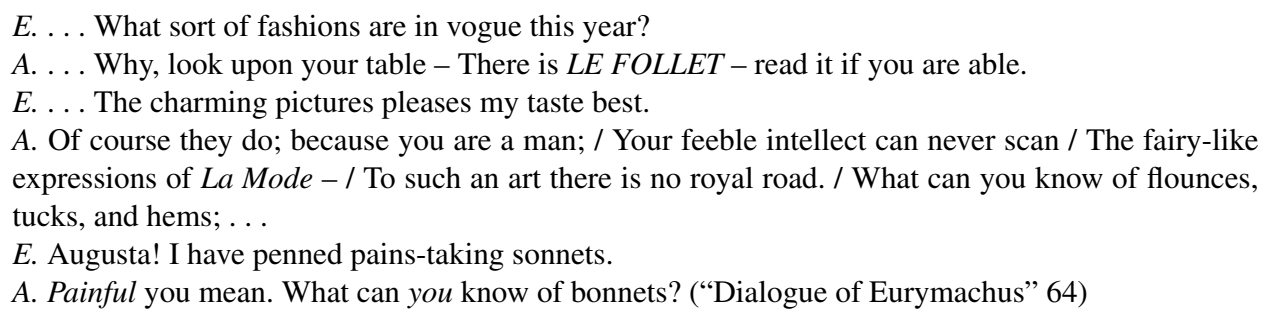

Fashion is supposedly a feminine realm too mysterious for man's "feeble intellect." Is this a man's view or a woman's view? To know for sure is to lose the fun of all the twists of a man imagining himself in a woman's body looking back on himself, who might be a woman taking on a man's name in the first place. Le Follet, as the fairy light of "La Mode" or the ghostly medium of the fashion-word, survives best in freeing its vision from any fleshy sex and yet making use of all the versatility that a bifurcated and bifurcating sexuality can offer.

Fashion, whether as vision, intelligence, image, or object, is ambiguously paradoxical. It is largely in dealing with this modern bugbear of ambiguity and paradox that the English novel comes to its maturity and substantiality in the mid-nineteenth century.

\section{Fashion, Fashionable Intelligence and the Victorian Novel}

BECAUSE OF ITS PERVASIVENESS, it is impossible indeed to list all the evidence major Victorian novelists have left behind about their acute consciousness of fashion, the beau monde, and fashionable intelligence as different expressions of a new modern force in the turbulent life they were in. A couple of more obscure examples may go a long way. George Eliot, whose fiction focuses more on rural England than the London-Season-centered fashionable life, frequently betrays her fashion consciousness in being "defensive and self-conscious" about 
her leaning on the side of the unfashionable (Williams's 81 ). ${ }^{17}$ She calls her partner and herself "two secluded owls, wise with unfashionable wisdom" (Life and Letters 2: 558). In her novels, she would, from time to time, defend her tone of stress as opposed to the "light vivacious tone of fashionable life" Tony Jobling assumes in Bleak House (506; ch. 32): "In writing the history of unfashionable families, one is apt to fall into a tone of emphasis which is very far from being the tone of good society" (Mill on the Floss 31; vol. 2, bk. 4, ch. 3). Such "self-conscious and defensive" gestures, however, are not the only ways in which the fashion-unfashionable norm enters her life, mind and writing. For instance, when she presents the Middlemarch residents' view that Dorothea Brook is "kissing his [Mr. Casaubon's] unfashionable shoe-ties as if he were a Protestant Pope" (58; bk. 1), or when she pens a Jewish man like Daniel Deronda as a spiritual guide for such a woman of fashion as Gwendolen Harleth, etc., we students of Victorian literature and culture have to ask a more general question: How does the conscious or unconscious entrance of fashion into, not only George Eliot's, but Victorian fiction in general, shape its development?

My sweeping argument is that modern fashion bends everything towards its own image as a pure medium - the "mould of form" - and thus its entrance into the Victorian novel inflects the latter's constructions - in theme, narrative, language and character - all towards a medium concern, an urgent desire to merge the virtual and the actual, to stand simultaneously subject/self and object/other, to be nothing and yet everything like the glass of fashion in the dialectical exchange between space and time. Dickens's Bleak House is the best case for this study since coming out right in the middle of the century, it registers most strongly the fashion-medium concern and in its turn serves as a mirror of fashion for later Victorian novels.

\section{Thematic Issues}

THEMATICALLY SPEAKING, ALMOST ALL Victorian novels grapple with the world of fashion to imagine what a viable community might look like in the levelling age of mechanical (re)production even as different writers have different approaches. William Makepeace Thackeray, for example, often features the world of fashion only to satirize and criticize it but does not offer a new blue print in its place. Anthony Trollope also focuses substantially on the world of fashion but has done away with Thackeray's - and Dickens's at that - satirical and cynical pose; he looks at it earnestly to see how modern England works and/or might regenerate itself.

Some fundamental thematic issues shared by many Victorian novels include: How can we still build a tenable human community when a small but leading part of society - the beau monde - is taking society on an increasingly virtual journey, moving itself away from the land-based emotive and cognitive, as well as economic and familial, model of existence? How do we tackle the enormous wastes and ruins - like Tom-All-Alone's, like the Dorlcote Mill in bankruptcy - in the midst of prosperity? How can we recycle the "wasted people" - the marginalized, the ruralized, the refused and deserted people, i.e., the "terraqueous" orphans on the "terrestrial globe" 18 - like Jane, like Lucy, like Joe, like Oliver, like Hetty, like Mirah into fashion's bound/unbound serialities as virtual communities now?

Victorian novelists might not raise these questions directly and do not provide same, settled, or even real answers, for sure, but the frequent recurrence of certain linguistic styles, certain narrative structures, certain characterization techniques - as will be detailed below make these questions tangible. 


\section{Language}

ACCORDING TO BAKHTIN, THERE ARE some fundamental "stylistic-compositional unities" that help render the novel into a "heteroglossia": "authorial speech, the speeches of narrators, inserted genres, the speech of characters"; and it is just "by means of the social diversity of speech types [raznorečie] and by the differing individual voices" that the novel "orchestrates all its themes, the totality of all its objects and ideas depicted in it" $(262,263)$. With full respect to Bakhtin's argument, I'd suggest that the novel does its job of orchestration by a general reference to fashion. Fashion is not just one voice among many but the underlying principle, or rather the meta-language, that sets in motion, catalyzes, and regulates the interactions among the novel's "differing individual voices" as well as "the totality of all its objects and ideas."

An illustrative example of fashion's underpinning of the different speech types in the novel can be found from Bleak House's first installment. It is not accidental that Dickens names his second chapter "In Fashion" and writes like this:

My Lady Dedlock has returned to her house in town for a few days previous to her departure for Paris, where her ladyship intends to stay some weeks; after which her movements are uncertain. The fashionable intelligence says so, for the comfort of the Parisians, and it knows all fashionable things. To know things otherwise, were to be unfashionable. $(57 ;$ ch. 2 )

Here, the working language is that of "fashionable intelligence" reporting on a woman of fashion's movement just as in the Morning Post. Yet by some slight twists in diction and tone, Dickens activates fully what Bakhtin would call the "dialogic imagination." In adding "My" to a seemingly objective, third-person fashionable report, Dickens enlivens several voices here. First, there is the mute but complacent reading voice of the husband who just needs a quick dive into the newspaper to confirm that "My" lady is there. Then, there may be the tentative voice from one of the Dedlock circle using fashionable intelligence to decide his or her next move. Finally, there can also be respectful, servile and even confused voices of downstairs people; or the slippery tongues from related merchants like "Sheen and Gloss"; or even the "light vivacious tone" of a fashionable reader like Tony Jobling, who claims the virtual idol as "My." Via a small addition, Dickens issues a live show of a community brought together by fashionable intelligence, each member speaking its core language in his or her different tone and manners. So far, the authorial discourse is fully immersed in all those voices; there is no alternative tone above those different speech types. The authorial voice is heard only after a varied but full quotation of fashionable reporting, when Dickens specifies that "The fashionable intelligence says so. ..." From here on, we hear a satirical voice from the implied author.

Doubling on the anonymous narrator, the implied author satirizes the self-constituting, self-reflexive nature of "fashionable intelligence," revealing its claim to omniscience - "it knows all fashionable things" - to be by nature limited, exclusive, and willfully neglecting of what is deemed unworthy of knowing: "to know things otherwise, were to be unfashionable." Yet because what is "fashion/unfashionable" is "uncertain," its limitedness and exclusivity simultaneously exude the beauty of openness and freedom. Such ambiguity allows fashion or fashionable intelligence to pass through satire unscathed; for despite the sharp satirical tint of the authorial voice, Dickens bases its narrative structure fully on fashion's dynamic exchange between rest and motion, rendering the novel a procession of a full fashion cycle. 


\section{Narrative Structure}

WHILE IT IS OBVIOUS, NO CRITIC has yet commented on the fact that the novel's serialization extends through two London Seasons and thus can seamlessly map its key narrative moments into a complete fashion cycle. As the first installment occurs in March (1852), the beginning of the year's season, we have Lady Dedlock, still "In Fashion," at the "center of the fashionable intelligence, and at the top of the fashionable tree" $(57$; ch. 2). When the last installment comes out around the end of the Season in September (1853), Lady Dedlock has gone out of fashion and Chesney Wold abandoned by the World. Throughout the year and half in between, every big move of hers is released as monthly "fashionable intelligence," even as the fictional news may not always dovetail with the actual "fiend" of the moment. For instance, the fifth number of the novel comes out in July, the climax of the London Season, when a fashionable lady should, normally, be featured in "Fashionable Gaieties"; against this background, to present Lady Dedlock in a ruined place like "Tom-All-Alone's" allows Dickens to subtly deploy contrast for multiple novelistic purposes, as will be detailed later. Suffice it here to say, the whole novel can be read as one woman's going out of fashion and another's - Esther's - getting in, with two narrators doubling largely on the "fiend" to regulate the "Arrivals" and "Departures" of two large "retinues" of characters and things, monthly in and monthly out.

In spite of the anonymous narrator's satirical gesture, he integrates "fashionable intelligence" implicitly and explicitly into his narrative:

It has left off raining down in Lincolnshire, at last, and Chesney Wold has taken heart. Mrs. Rouncewell is full of hospitable cares, for Sir Leicester and my Lady are coming home from Paris. The fashionable intelligence has found it out and communicates the glad tidings to benighted England.

(203; ch. 12)

Before coming to the third sentence, readers would assume that all that goes before originates from the anonymous narrator; the third sentence, however, wakes them up, calling their attention to the existence of another voice this narrator is mimicking. If the anonymous narrator does not like the servile and eulogistic report of the "fiend" and mocks it by a satirical tone and tongue-in-cheek manner, he nonetheless uses the latter's intelligence as part of his own narrative. For his own plot line continues seamlessly from where "fashionable intelligence" stops: the expected homecoming of the Dedlocks stirs up Chesney Wold to prepare for their arrival. Thus the anonymous narrator confirms that the fashionable intelligence is, after all, true. This pattern of doubling followed by differentiation followed by confirmation occurs not infrequently in the novel, suggesting Dickens's awareness of the difficulty in absolutely differentiating his narrator from the "fiend."

Indeed, I would argue that Dickens's real aim in the novel lies not in differentiation but in experimentation. He is trying out a new omniscient narrator who is based, not so much on the Judeo-Christian God - as is widely assumed ${ }^{19}$ - as on the newly emerged, selectively knowing and yet quite almighty "fashionable intelligence" with one major difference: in tune with what Andrew Miller calls the Victorian "moral perfectionism" (1-34), Dickens endows his narrator with an ethical eye that sees what the "fiend" willfully neglects.

Like the "fiend," Dickens's omniscient narrator has the capacity to "fly" like "the crow" so as to be "in" that extraterrestrial place of fashion in the midst of "the void" and broadcasting what can only be termed "fashionable intelligence" in modern society (55; ch. 2). The whole 
second chapter titled "In Fashion" is his fashion statement for the month of March where he provides, first of all, many pieces of "fashionable intelligence" per se, such as where the woman of fashion is, what objects she is using - the beautiful hand-screen for instance, and what view she just had and is having - the "Indian ink" kind, for example (56; ch. 2).

Like the "fiend," the omniscient narrator is both a voracious collector of objects and a minute differentiator of them. Apropos of Barthes, it has been widely known, that some objects in fiction do not have much structural function other than to build up the sense of "the real" for the novel ("The Reality Effect" 141-48). It should be specified that these reality-effect objects - whether wittingly or involuntarily picked up - are seldom obscure; their entrance and movement within the novel are in tune with the decree of fashion. Both Indian ink and hand-screens, for instance, were featured in fashion columns and enjoyed high visibility in the first half of the nineteenth century. Via seemingly innocent and natural references to them, the omniscient narrator seamlessly sets himself up as an insider, an authentic source of fashionable knowledge, and thus a reliable narrator.

Once his credibility is built up, the omniscient narrator will also play, again like the "fiend," the role of a "mighty hunter before the Lord" (210; ch. 12); only his "Lord" is not the traditional master but the new, undefined, fashionable reader. This "mighty hunter" is first of all a harbinger, preaching directly that the world of fashion is not "unlike the Court of Chancery," both being "things of precedent and usage" (55; ch. 2). Yet, he can also position himself like a watch dog, begging "your Highness" - the fashionable reader embodied by the queen maybe - to see the limitation of the current world of fashion:

But the evil of it is, that it is a world wrapped up in too much jeweler's cotton and fine wool, and cannot hear the rushing of the larger worlds, and cannot see them as they circle round the sun. It is a deadened world, and its growth is sometimes unhealthy for want of air. (55; ch. 2)

If the "evil" and "deadened" nature of the current beau monde calls for reform, reform probably won't happen unless the "fashionable eye" becomes ethical.

Fully in tune with the abstract essence of "fashionable eye" as a magical mirror of elsewhere, the anonymous narrator gradually twists it for ethically-sound contents. Thus, as the novel moves along, the omniscient narrator's intelligence diverges more and more from the "fiend." For instance, in Chapter 16, when the "astonished fashionable intelligence hardly knows where to have her" - the "restless, very restless" fashionable Lady Dedlock (270) - the omniscient narrator nonetheless follows her to the ruined place, revealing what the former willfully ignores: the concourse of fashion goes two ways. ${ }^{20}$ If this ethereal atmospheric carrier is sustaining of life, it can also take the deadly virus from Nemo to Jo to Charley to Esther, leaving on its way dead bodies as well as wasted entities. Part of the omniscient narrator's ethical job above the ruthlessly dogging "fiend" is to recycle some of the waste into fashion's order of visibility, which admits only two kinds of identities: "Fashionables and Nobodies" as the German Prince Pückler-Muskau once wrote (154). To do this, the omniscient narrator must give some room to the feminine side of fashion, to its tendency for rest and stillness in its overall onward rush.

It has been widely noticed that Esther's narrative is a clear contrast to the other "impersonal narration, in the historical present, by an omniscient observer" who is, "without a doubt, male" (Gravil 80); what is seldom explored, though, is the dynamical intricacy between the two narrators that can be fully characterized only by the dialectical exchange between 
fashion as rest/space and fashion as motion/time. Generally speaking, Esther's narrative bends the onward rush of the male narrator's narrative towards a different direction, slowing it down and providing it with a vertical seriality that is inward-oriented, domestically located, personal, innocent, as opposed to the man's outward-oriented, public, worldly-wise seriality, although it can be the other way round as well at certain moments.

Esther starts her narrative by a timid and yet decisive act of bending:

I have a great deal of difficulty in beginning to write my portion of these pages, for I know I am not clever. I always knew that. I can remember, when I was a very little girl indeed, I used to say to my doll. ... And so she used to sit ... staring at me - or not so much at me, I think, as at nothing - while I busily stitched away. . . . (62; ch. 3$)$

By acknowledging her inadequacy in beginning to write, Esther immediately differentiates herself from the "mighty" "fashionable intelligence" or the omniscient narrator; nonetheless she makes it clear that she is not only aware of the other but is actually called on by the other to write her "portions of these pages." With Nemo as her natural father and a still-fashionable Lady Dedlock as her natural mother, Esther has been unwittingly authored, written and still being under-written by the fashion-dominated industrial capitalism and its fashionablenobody order of visibility. ${ }^{21}$ Thus, from the very beginning, Esther is faced with the task of recycling herself back into the system by the only way available: refashioning, re-writing or re-constructing an identity. Since in modernity, a subject has been at any moment shot through by the eternally present "breath" of fashion as time and underwritten by its fashionable intelligence, any initiative on her part is a re-building, a Benjamin-style "tiger's leap into the past" or into fashion's baseless fabric of light and vision (Illuminations 261), retrospectively collecting all relevant pieces scattered in the chaotic mass and re-piecing them into a managed and manageable whole, in tune not so much with the sparkles of voluntary or involuntary memory, as with the anticipation of a good future wherever it is. In this sense, Esther is only literally contracted "to write my portions of these pages" with the anonymous male narrator of the novel, for whom she serves as the body of light. Metaphorically, her contractor is fashion itself, or rather the willed or willful human aspect of fashion for a standstill, for a momentary and creative materialization into dialectical images that start with a diving from the present into the past only to re-emerge in the future as still in the present, for they are one in fashion. Thus Esther's narrative, although mostly in past tenses to commemorate memory, must be understood in the light of those brief statements in present tenses: "I don't know why. At least I don't think I know why. At least, perhaps, I do, but I don't think it matters" (288; ch. 17).

Perhaps no other narrators in the Victorian novel can sound so uncertain like Esther and thus so fully fleshes out the present moment of writing and recalling as just a brief pause, a mere standstill in the ceaseless flow of fashion, fading faster perhaps than those past moments her memory would not let go. Her narrative, i.e., her collection of momentary standstills, thus highlights consciousness - that mirrored depth and opening from which "I" remember, differentiate, hope, speak, and do, however tentatively or vainly. This personalized narrative breaks up the surface flow of the impersonal masculine narrative with other-direction-oriented serialities, turning each serial number into a constellation of opposite forces that provides relative stability and completeness, as well as a chance to dwell in incompleteness and uncertainty. ${ }^{22}$ Via the dialectical interaction between two kinds of narrative within each serial 
and/or between two numbers, the quintessential Victorian novel Bleak House has quietly extended into a long duration that does not feel so since the yin and the yang balance each other out nicely. If at the beginning, it is the male narrator who calls on Esther to join the flow and seemingly controls her participation in it, in the end it is Esther's narrative that provides some sort of closure to the male narrative and to the overall flow. That Esther can write herself into the system has much to do with her efforts to differentiate herself from and in some sense abandon the current fashionable lady - her own mother ${ }^{23}$ - but not the "fashionable way" per se ( 333 ; ch. 20$)$, which emerges again in the characterization of the densely-populated novel.

\section{Characterization}

IT'S HARD TO THINK OF A Victorian novel that does not have a group of people who are, like the Guests in Mill on the Floss, the "glass of fashion" (541; bk. 6, ch. 6), via whose mediation other characters are brought to view anew and positioned or re-positioned in the novel's virtual landscape. In Bleak House, for instance, there are three openly-alleged fashion-driven characters on three different levels of society: the fashionable-intelligenceaddicted Tony Jobling, the Model of Deportment Mr. Turveydrop, and the fashionable Lady Deadlock; each, in giving mirror images of those nearby, sets in motion interactions that finally empties the virtual space of fashion of its old content and frees it for another cycle.

Lady Dedlock is the most "brilliant and distinguished" glass of fashion via which all other characters are sooner or later mirrored and transformed into doubles of their former selves, which, no longer coinciding with what they'd be at any moment, must "move on" or be moved to unknown destinations only fashion/fate/time knows where. The orphaned crossing-sweeper Joe, for instance, should be most far away from this glass of fashion; yet fashion's uncertain and providential logic initiates him into the purview of her mirrored pool of society via the emotionally generous yet financially pitiable kindness from the law hand Nemo, the former lover of the fashionable lady. Because of a chance encounter, he is no longer just a sweeper but has a double as an inseparable piece of the puzzle of fashion: how does Captain Hawdon - a rake in fashionable society whose name sounds the same as Haut Ton, the French term for high fashion - turn into Nemo - "Latin for no one" (185; ch. 10)? Once the fashionable lady's brilliance flits on him, Jo is destined to pick up by association and contiguity the medium function of the glass of fashion and thus become a visual object seen not for itself. As a mere container for other people's desires and fantasies, he is doggedly searched out by the lawyer Tulkinghorn as the key to some Dedlock or dead-lock truth, by the police-detective Mr. Bucket as a target of his "duty", by the legal clerk Mr. Guppy as the missing stone in his imagined path to fashion and greatness, and by the overly imaginative Mrs. Snagsby as a clue to her law-stationer husband's hidden sexuality. All these virtual identities of Jo are to confuse him and move him on incessantly until death brings him to that final place of rest: the unconsecrated burial ground where Nemo and all other non-entities have lain.

That Lady Dedlock is also to be found dead on this ground for nobodies testifies to the rate and range of change in modernity. High fashion can dwindle quickly into Nemo, and the glass of fashion can soon lose its brilliance and distinction, lying a "distressed, unsheltered, senseless creature" indistinguishable from any lower-class bodies (868; ch. 59). 
That is Dickens's painful and pungent insight into fashion's relentless levelling rush, an insight that can only end in despair worse than death if something else does not occur at the same time and on the same spot, and this is exactly what happens: by a willful change of heart, the death scene - both of Lady Dedlock's and of Jo's - bodies forth not as that of separation but that of return to human communion in love and sympathy, in what Alexander Bain would call the "pleasure of the embrace" (126); Lady Dedlock's embracing of the bar of the iron gate and Jo's last wish to be carried to the side of Nemo who "was good to me" speak strongly of the necessity to construct another order of human sociality that might not subvert fashion's single-tautology order of visibility but can twist its abstract essence for ethically solid purposes. This willful construction is exactly what Dickens does by highlighting another four major kinds of character types based on the model of fashion but different from the Lady Dedlock-Jo-Nemo pattern.

One type clusters around Tony Jobling, a shabby genteel young man who holds on to fashion and whiskers as the last tie to his supposedly "high aristocratic turn" (814; ch. 55). Short of means, Jobling cannot but be a dim and yet viable mirror, some evidence of which is registered with the fact that Mrs. Piper, "who leads the [Cook's] court," would like "her Jonny" to have whiskers "identically like that young man's" (341; ch. 20). Via this Weevle mirror of fashion, those masses of anonymous entities in Cook's Court recur, no longer simply as the poor affiliates of the Court of Chancery, but also as virtual citizens in modern fashionable-intelligence-mediated community on a cosmic level. For the Cook's Court has "Sol's Arms," from which Tony Jobling borrows yesterday's newspaper to "know the world and be known by them" (340; ch. 20). Once this mirror is set up, Mr. Snagsby's characteristic tag "not to put too fine a point on it" becomes more than a personal eccentricity crystalizing his relationship with his "little woman" whose mother used to "lace her up with her maternal foot against the bed-post for a stronger hold and purchase" (179; ch. 10); it also marks his entry into that atmospheric fabric of fashion where a "fine point" is, not only that ethereal breath of the mouth, but also a delicate pattern of stitches on a piece of lace, as the Household Words essay the "Belgian Lace-Makers" explicates (321). Similarly, Mr. Guppy finds a double in and via this Jobling mirror of fashion. Although it is Guppy who swims around, working to feed the double, it is Jobling who provides him with the language of the soul, as well as motivating and mnemonic linkages such as the former's collection of the Gallaxy Gallery of British Beauty, which guides him in his aspiration for and effort at his sometimes-frustrated but never-blocked movement toward the West End. For this Jobling circle, Dickens's ethical eye is quite benign, subjecting them to light satire but no poetic justice.

Like Tony Jobling, Mr Turveydrop mirrors another pool of characters who are defined by their avatars in the virtual world mediated by fashion. There are in fact two swarms in this pool. One consists of Mr Badger, Mr Chadband, and Mr Skimpole. Identical mirror images of Mr Turveydrop, these characters share his defining characteristic: the reification of fashion's rest mode in just one kind of spatial extension over time. Turveydrop's habitual focus is deportment, Badger's his wife's three former husbands, Chadband's oily slippery speech, and Mr Skimpole's assertion of himself as a child. Seemingly turning topsy-turvy the dominant model of identity construction in fashion - i.e., one of constant changes in an endless duration with only the empty name/form/medium remaining the same throughout these characters actually literalize one of its key aspects: fashionable changes over time are in its ultimate sense the return of the same dark enigma of life in different shapes; only with 
them, the different shapes of the eternal return turn out to be the same each time! Thus in an age of "meteors ... shooting across the fashionable sky" (340; ch. 20), they provide the comfort of stability and permanency of stars; they are paradoxically more permanent fashions. That might be why these "flat" characters are "easily recognized," "easily remembered," and "provide their own atmosphere," as Forster would say of the type (68-69). We have to take Forster's metaphorical "atmosphere" literally, though; the atmosphere Mr Turveydrop and his like provide is the "breath" of fashion on the cosmic level, in its ethereal or golden or blue streaks. For this Turveydrop group, Dickens's ethical eye is sharper, scrutinizing them with stronger satire but still no poetic justice.

Krook, Tulkinghorn, Vholes, and the Smallweeds would have belonged to the above pool if not for the sinister nature of the more permanent fashions they repeatedly present over time. Krook's "well" of waste only buys and never sells because he is searching for the absolute "rag" or "bottle" - that unanalyzed something that makes Jarndyce \& Jarndyce visible in and out of Chancery. In other words, he is searching for fashion as the pure medium in all its vagueness or clarity his illiterate mind can grasp. This search is of course doomed by his blockage of what fashion favors most: circulation; and he dies a "natural" death of fashion - burning itself in one object only to re-emerge in another: Krook's ashes would add on to that no longer ethereal but instead darkened, greased, tangible and all-penetrating fog - a drastic image of fashion as atmosphere with the "death of the sun" (49; ch. 1). Similarly, Tulkinghorn continually returns as the dark material on the other side of the glass of fashion, his death being the downfall of the fashionable lady as well since they virtually share one body; meanwhile, Vholes perennially presents his "bloodless quietude" and the Smallweeds their paralyses in petty capitalist concerns. For this pool of characters, Dickens's ethical eye is quite relentless.

In contrast to the swarm of characters who have more or less of a permanent fashion, Dickens sets another that reifies fashion's restless spirit. Chief among this group is Richard Carstone, who is attracted to "bright buttons" - i.e., to the "polite show" business conducted everywhere in modern England not just by individuals like the Master of Deportment but also by institutions like the Chancery, the Church, and the Police (399; ch. 24). Unfortunately, this fashionable tint does not help button him down to any profession or object other than the everreceding court judgement on the Jarndyce v. Jarndyce case. Whereas other restless spirits like Mrs Jellyby have the luck to transform their restlessness into one project after another quite independent of the human effects of each - in fact this ethical indifference is indispensable for the quick shifts - Richard's personal implication in the Chancery dooms his legal pursuit - his last in a series - on earth. For his desire for final judgment, like Miss Flight's, runs counter to the essence of fashion as a dialectical exchange between time and space, which favors small chancy closures but no final word, because the final word is already there in the beginning - it is the empty name/form of fashion or law or other institution that will be perpetuated from beginning to end. Unable to realize this, having no engaging profession, and boasting no wealth to afford a constant pursuit of fashionable gaieties as the purpose of life, Richard has nothing but death to initiate him into a new series in another world. The death of this promising individual feels particularly pathetic in an age of secular individualism when even the Church has gone the "fashionable way" and is captured by a sort of "Dandyism" (210; ch. 12). Yet again, Dickens's despaired vision is accompanied by a redeeming image: there is a little Richard carried actually in Ada's womb and virtually in what I would call Esther's "maternal mode" of human connection. 
Although Esther as a character "has caused problems right from the start" for both contemporary and later critics, ${ }^{24}$ I would argue that she is one of Dickens's most pungently, most carefully penned characters; in many ways, she registers Dickens's - and to some extent other Victorian intellectuals' - most painful thinking on some crucial issues of modernity as framed by Sean O'Toole in his study on habit in the English novel: "what it means to have an 'identity' in an increasingly modern age" (5); "what it means to 'be' or 'have' a character in modernity (37). It's my contention that with Esther, Dickens constructs a maternal mode of being and knowing that is based on fashion as the pure medium but has twisted its dialectical exchange between time and space for ethically sound purposes.

Esther starts with what is quintessentially the orphaned status of any modern subject, male or female. Cut off from the "Great Chain of Being" with God as the ultimate meaning giver, she is extremely lonely, isolated, a pure non-entity with a rhetoric of negativity:

I have not by any means a quick understanding. ... I was not charming. ... I never loved my godmother. ... I had never heard my mama spoken of. I had never heard of my papa either. . . I knew none of them [school girls] at home. . . . I never went out at all. $(63-65 ;$ ch. 3$)$

Such a creature cannot but be feminine and feminized in the traditional Judeo-Christian patriarchal sense. The point, however, is that she is not exactly or rather merely a victim of that weakened and destabilized religious system; she is also a modern being, albeit a wasted product; her rise from "no one" to "someone in authority at Bleak House" follows the movement of la mode but with the note of soft care and mothering taking place of fashionable indifference and relentlessness (94; ch. 4).

As both character and narrator, Esther is no less mobile and circumstantially shaped than other characters and the male narrator; the only difference is that wherever she moves, she notices and nurses other people. From Ada and Richard to Jo and Charlie and the brickmakers' family and to Jarndyce and Woodcourt - from town to country and back - she mothers all the way through. Any place she steps into, she is going to turn it more like a home, home no longer based on blood, land or even stable economic links but solely upon chance encounters structured by human feelings and the will to ethics. She has no self beyond that materialized in her care for others. In this sense, it is right for critics to share Garis's view that "she is empty," "has no convincing inner life," and "has no will, no sense of ego, hardly an identity at all" (141-42). What such a view ignores, however, is that Esther's emptiness and lack of ego are not a sign of Dickens's having done "a coarse portraiture" as the Spectator review put it (qtd. in Geraghty 34), but of Dickens's painful insight into modern identity in its most despairing light: it is an empty form like fashion that has to be filled and refilled constantly on the journey in tune with the demand of circumstances and with the "real" identity always yet to be born; the best one can do is to carry an ethically solid principle onto each leap one has to make together with fashion. Thus, Esther's willingness to take John Jarndyce's offer of marriage in spite of her love for Allan Woodcourt does not betray her lack of ego or self because there is none settled enough to be betrayed - but instead evidences her strong will not to let her principle "to do good" fall through in a trying situation (550; ch. 35). Esther passes the challenge and remains a consistent embodiment of Dickens's new ethically viable image of fashion. True, though, such a character might be "as unrealistic as Krook and Skimpole" as the Athenaeum review finds Esther (qtd. in Geraghty 34), but it is true only when the real is equated with the actual. In the new fashion-mediated framework where the virtual is the 
real, Esther is absolutely real since she is absolutely virtual: she is the ideal "mould of form" Dickens constructs to replace the current mode. Partially fleshed out by other characters like Allan Woodcourt, George Rouncewell, John Jarndyce and the Bagnets, this ideal highlights the maternal as a new other-oriented, hubris-reduced, range-limited and yet still mobile and circumstantial mode of fashioning human community out of the turbulent flow.

That this mode does not do away with fashion's self-reflexivity is subtly suggested in the novel. From time to time, Skimpole would insinuate that Jarndyce's charities are selffulfilling activities and that Esther is "intent upon the perfect working of the whole little system of which you are the center" (587; ch. 37). Dickens's ambivalence about the maternal mode, however, is most strongly felt in the comparison and contrast he sets up between Esther and the professional detective Bucket. Like Esther, Bucket is admirable for his emphasis on and good performance of "duty." Yet, as D. A. Miller argues, there is a "historical ambiguity" concerning the question for whom or what the Detective Police does its policing (79). $\mathrm{He}$ cares little about the social and personal implications of his pursuits, which is particularly conveyed in his moving Jo onto death. What matters to the detective police seems just the hustle and bustle, chase and chisel of duty; no matter for whom or what Bucket works, he makes a game of the demanding job and derives pleasure from the process. In this sense, one piece of duty means about the same to him as another. The only principle he follows in performing a piece of duty is, tautologically, if duty permits or "forbids it" (774; ch. 53). This self-reflexive gesture aligns the detective police seamlessly with the system of fashion: Bucket's duty as a detective lies ultimately in detecting duty to fill himself up. More than Rouncewell, Bagnet, Turveydrop and Chadband, Bucket materializes perfectly the image of a container with the void as its fourth dimension - that of time, that of fashion as the pure medium with no core to it, ethical or otherwise. A cold, ethically indifferent Bucket, though, can easily pick up the temperatures of the cosmic stream passing through it. He can become funny and interesting - albeit suggestively discomforting on a deeper level - as when he poses as a "swell" in front of the mirrors in Lady Dedlock's boudoir and reaches his hand into the various drawers $(821$; ch. 56). He can also be tenderly warm as when he is with the Bagnets or before the dying Gridley. Meanwhile, a Summerson - a supposed source of light and warmth like that brilliant object in the sky - might turn out cold, after all, if with that empty core of ethics attached to her.

Dickens's - and for that matter, many other Victorian intellectuals' - ambiguity in thinking through modernity is in the end that of fashion itself - that is, as it dashes forward in the void of the blank page: threateningly overwhelming yet excitingly open to possibilities.

New York Institute of Technology, Nanjing

\section{NOTES}

The author wishes to thank John Maynard and Adrienne Munich for their insightful feedback on an earlier version of this article. She is also grateful to Adela Pinch, John Kucich, Martha Vicinus and Mary Kelley for their guidance on her research in Victorian studies.

1. Spec. Coll. Hepburn 186, University of Glasgow. Web. 14 June 2016. Emily Steinlight also features, though interpreting quite differently, this ad and others in her exploration of advertising and the Victorian novel (132-62). 
2. Hazlitt says that fashion is nothing but the "prevailing distinction of the moment" (149). The Court Journal frequently refers to fashion as the "dictator of the hour"; see, for instance, "The Influence of Example in the Fashionable World," 213.

3. For example, Mrs. Gore and Theodore Hook frequently use this term in their works.

4. See Byrde, Harvey, Perrot, Ribeiro, Steele, and Walkley for nineteenth-century fashions.

5. See Breward, Choudhury, Shannon, and Sloan.

6. For the modern turn in Dickens's studies, see John's introduction to Dickens and Modernity (2012). To John's succinct summary of this critical trend, I would add some more recent works, including John's Dickens and Mass Culture (2012), Piggott's Nineteenth Century: Dickens and Benjamin (2012) which compares the eponymous writers in terms of modernity, and McKee's Reading Constellations: Urban Modernity in Victorian Fiction (2014), which uses Benjamin terms to read Dickens, Hardy and James. For the material turn, see Brown, Freedgood, and Hack. For the psychological/cognitive turn, see Beer, Cohn, Dames, O’Toole, Ryan, Rylance and Taylor.

7. My terming here is influenced by Lehmann's exploration of fashion as a "paradigm of modern culture" in his 2000 book Tigersprung (xiv). Via a substantial investigation into the "meaning of fashion that goes beyond notions in the sociology or psychology of dress" (xiv), Lehmann has traced a philosophy of fashion as the paradigm of modernity with continental writers from Baudelaire, Gautier and Mallarmé through Simmel and Benjamin to Aragon and Breton.

8. Watt talks about how the novel as a literary vehicle of an originality-valuing culture is well-named in this sense (13).

9. In her poem "Fantasies," Landon writes: "I'm weary, I'm weary, - this cold world of ours; / . . / Where the beauty of night, the glory of dawning, /Are wasted, as Fashion, that tyrant, at will / Makes war on sweet Nature, and exiles her still (128; 1.1-8).

10. See for instance, "Rambles in Turnbridge Wells," 305.

11. In his introduction to The Structural Transformation of the Public Sphere, Habermas talks implicitly about the old sartorial-symbolic mechanism. For him, "lordly" and "publicus" were synonyms in the feudal society of the High Middle Ages; lordship by definition was "something publicly represented", and representation in this context meant exactly to make "something invisible [i.e. the manorial lord's status as an "embodiment of some sort of 'higher' power] visible through the public presence of the person of the lord": hence the "publicness (or publicity) of representation" (6-7). Kuchta devotes a chapter to what he calls the "old sartorial regime" (1550-1688) in his 2002 book The Three-Piece Suit and Modern Masculinity.

12. McClintock, for example, speaks of the "aristocratic body as a "theatre of sumptuary and sexual display" (174).

13. According to the British historian Anderson, "new advances in printing technology, reductions in the newspaper tax and paper duty, and widening demand for reading matter" made possible not only "the low-cost, high-speed dissemination of the printed word" but also the "profitable, mass reproduction of diverse imagery" between 1830 and 1860 (1-2). For Anderson, the "pictorial character" became "the hallmark of a transformed and expanded popular culture," and the "printed image more than the word represented a cultural break with the past, for it demanded neither formal education nor even basic literacy" (2-3). In many cases, the "pictorial character" came out via the column of fashion, which usually included some fashion plates, descriptions of these plates, and statements of the general movements of the fashionable world.

14. I am quoting from the New Yorker's fashion reporter Fraser. In discussing fashion in the1980s, Fraser laments its going beyond the limits of lifestyle trends and material pursuits to "seep down into the realm of those profundities, verities, and values which used to be called moral and spiritual" in the late twentieth century; within that context, Fraser proposes the idea of the "fashionable mind" and defines it as that which "sees every aspect of life through the looking-glass of fashion" (146). While Fraser does not track the origin of this term, one can certainly find its use in nineteenth-century periodicals. 
15. For more of Anderson's notion of seriality, see Chatterjee. While Chatterjee insightfully sees the murkiness between Anderson's "bound seriality" and "unbound seriality," my point is that fashion is a dialectical exchange between the two.

16. Sennett asserts that appeal to "potency" - as embodied by the inexhaustible songs an iPod might provide - is a key feature of the new capitalist culture in recent decades (155).

17. These epithets are Williams's (81). In elaborating on the same quote I am to use in the text, Williams nonetheless goes in a direction quite different from mine (78).

18. Both are nineteenth-century coinages, referring to the unfashionable, as in "Fashionable Tactics No. VI," 771.

19. Scholes and Kellogg, for instance, claim that omniscience is "not a descriptive term so much as a definition based on the presumed analogy between the novelist as creator and the Creator of the cosmos, an omniscient God" (272). See also Jaffe, Vanishing Points, 1-2 and J. Hillis Miller 2.

20. In this chapter, Dickens raises the well-known questions: "What connexion can there be, between the place Lincolnshire, the house in town, the Mercury in Powder, and the whereabout of Jo the outlaw ...." While different critics have come up with different interpretations of this "connexion" - with the latest being Chappell's fantastic theorization of it as the "paper route" the novel traces (783) - it would not be too far-fetched to view fashion as this all-linking "connexion." And Dickens seemed to be specifically confirming this view when he brought out the following passage in Household Words in October 1853:

For we begin to think how many thousand men and women in England, how many millions more throughout the world, eat their daily bread by making and vending Fashion's elegant trumpery ... how ships, colonies, and commerce are all mixed up in a curious and yet congruous elaboration with this fal-lals: how one end of the chain might be my lady's boudoir and its nicknacks in Belgravia, and the other end a sloppy ship-dock on the hot strand of a Hoogley. . . . (Sala 194)

It seems that as soon as the fashionable season is over, Dickens is urging readers to think about fashion as an intangible but more positive "connexion" between things and people while in the midst of July's high fashion, he leans on its negative side.

21. For more about hero and author, see Easley's book on Dickens and Bakhtin.

22. While critical work has shed light on how the serial form harmonizes with "capitalist ideology" (Hughes and Lund 56), none has featured fashion as a perfect image for seriality, for the dialectical dynamic between part and whole, rest and motion. For more on the serial form, see Baker, Delafield, Drew, Erickson, Feltes, Law, Mackenzie and Winyard, Steinlight, and Vann.

23. See Dever, Schor and Jordan for their exploration of the mother-daughter relationship.

24. Geraghty 34. In her book on TV adaptations of Bleak House, Geraghty provides a succinct critical history of Esther's characterization (34-37).

\section{WORKS CITED}

Anderson, Benedict. Imagined Communities: Reflections on the Origin and Spread of Nationalism. London: Verso, 1983.

Anderson, Patricia. The Printed Image and the Transformation of Popular Culture 1790-1860. Oxford: Clarendon P, 1991.

Bain, Alexander. Emotions and the Will. $3^{\text {rd. }}$ ed. NY: D. Appleton \& Company, 1876.

Baker, Laurel. Print in Transition 1850-1910: Studies in Media and Book History. Palgrave Macmillan, 2001. 
Bakhtin, M. M. The Dialogic Imagination. Ed. Michael Holquist. Trans. Caryl Emerson and Michael Holquist. Austin: U of Texas P, 1981.

Barthes, Roland. The Fashion System. Trans. Matthew Ward and Richard Howard. U of California P, 1990.

Barthes, Roland. "The Reality Effect." 1975. The Rustle of Language. Trans. Richard Howard. U of California P, 1989. 141-48.

Bauman, Zygmunt. Wasted Lives: Modernity and Its Outcasts. Polity, 2004.

"Beau Monde (The)." La Belle Assemblée 1.1 (Feb. 1806): 5-7.

Beer, John. Post-Romantic Consciousness: Dickens to Plath. Palgrave Macmillan, 2012.

"Belgian Lace Maker." Household Words 1.14 (29 June 1850): 320-23.

Ben, Moore. "The Doll's Dressmaker Re(ad)dressed: Jennie Wren's Critique of Childhood, Femininity and Appearance." Victorian Literature and Culture 44.3 (Sept. 2016): 473-90.

Benjamin, Walter. The Arcades Project. Trans. Howard Eiland and Kevin McLaughlin. Belknap-Harvard U $\mathrm{P}, 1999$.

Benjamin, Walter. Illuminations: Essays and Reflections. Trans. Harry Zohn. New York: Shocken, 2007.

Berman, Marshall. All That Is Solid Melts into Air: The Experience of Modernity. Penguin, 1988.

Blessington, Countess. The Victims of Society. 3 vols. London: Saunders and Otley Conduit Street, 1837.

Bloch, Ernst. The Principle of Hope. 3 vols. Trans. Neville Plaice, Stephen Plaice and Paul Knight. Oxford: Basil Blackwell, 1986.

Braudel, Fernand. The Structures of Everyday Life: The Limits of the Possible (Vol. 1 of Civilization and Capitalism, 15th-18th Century). Trans. Siân Reynolds. New York: Perennial Library/Harper \& Row, 1985 .

Breward, Christopher. The Hidden Consumer: Masculinities, Fashion and City Life 1800-1914. Manchester UP, 1999.

Brown, Bill. A Sense of Things: The Object Matter of American Literature. U of Chicago P, 2003.

Buck-Morss, Susan. The Dialectics of Seeing: Walter Benjamin and the Arcades Project. Cambridge, MA: MIT P, 1989.

Byrde, Penelope. Jane Austen Fashion: Fashion and Needlework in the Works of Jane Austen. London: Ludlow, 1999.

Byrde, Penelope. Nineteenth-Century Fashion. London: Pavilion, 1993.

Carlyle, Thomas. Sartor Resartus. 1833 (serial). 1838 (book). Ed. Macmechan Archibald. Boston: Ginn \& Company, 1896.

Chappell, Patrick. "Paper Routes: Bleak House, Rubbish Theory and the Character Economy of Realism. ELH. 80.3 (2013): 783-810.

Chatterjee, Partha. “Anderson's Utopia.” Diacritics 29.4 (Winter 1999): 128-34.

Choudhury, Suchitra. "Fashion and the 'Indian Mutiny': The 'Red Paisley Shawl' in Wilkie Collins's Armadale." Victorian Literature and Culture 44.4 (4 Nov. 2016): 817-32.

Cohn, Elisha. Still Life: Suspended Development in the Victorian Novel. Oxford UP, 2016.

"Court Day (The)." The Court Journal 1 (2 May 1829): 8-9.

Dames, Nicholas. The Physiology of the Novel. Oxford UP, 2007.

Delafield, Catherine. Serialization and the Novel in Mid-Victorian Magazines. Ashgate, 2015.

Dever, Carolyn. Death and the Mother from Dickens to Freud: Victorian Fiction and the Anxiety of Origins. Cambridge UP, 2006.

“Dialogue of Eurymachus.” Le Follet 191 (1 Aug. 1862): 62-64.

Dickens, Charles. Bleak House. 1852-53. Penguin Classics, 1971.

Drew, John M.L. Dickens the Journalist: Models, Modes and Media. Palgrave Macmillan, 2003.

Easley, Keith. Dickens and Bakhtin: Authoring and Dialogism in Dickens's Novels, 1849-1861. New York: AMS, 2013.

Eliot, George. Daniel Deronda. New York: Crowell, 1893.

Eliot, George. Life and Letters. New York: Doubleday, Page \& Co., 1901.

Eliot, George. Middlemarch. 3 vols. Boston: Little, Brown \& Co., 1900. 
Eliot, George. Mill on the Floss. 3 vols. 7 books. Boston: Dana Estes \& Co., 1900.

Ellen, Janet. "The Press." La Belle Assemblée 149 (1 May 1821): 218-19.

"Empire of Fashion, The." Le Follet: Journal du Grand Monde, Fashion, Polite Literature, Beaux Arts, \&c. \&c. 20 (1 May 1848): 60.

Erickson, Lee. "Marketing the Novel, 1820-1850." Dickens and Victorian Print Cultures. Ed. Robert L. Patten. Ashgate, 2012. 71-82.

"Fashion in 1826." The New Monthly Magazine 19.73 (Jan. 1827): 88-96.

"Fashionable Entertainments." The Morning Post 24474 (19 May 1852): 5.

"Fashionable Gaieties of the Week." The Court Journal 49 (3 Apr. 1830): 214-15.

"Fashionable Herald." Bell's Life in London and Sporting Chronicle 131 (29 Aug. 1824): 277.

"Fashionable Nothings." The Court Journal 715 (7 Jan. 1843): 9-10.

"Fashionable Tactics, IV." The Court Journal 82 (20 Nov. 1830): 771.

"Fashionable World, The" The Morning Post 24396 (18 Feb. 1852): 5.

Feltes, N.N. Modes of Production of Victorian Novels. U of Chicago P, 1986.

Forster, E. M. Aspects of the Novel. New York: Harcourt, Brace \& World, Inc. 1956.

Fraser, Kennedy. The Fashionable Mind: Reflections on Fashion, 1970-1981. New York: Alfred A. Knopf, 1981.

Freedgood, Elaine. The Ideas in Things: The Fugitive Meaning in the Victorian Novel. U of Chicago P.

Garis, Robert. The Dickens Theatre: A Reassessment of Novels. Oxford: Clarendon P, 1965.

Geraghty, Christine. Bleak House. Palgrave Macmillan, 2012.

Gernsheim, Alison. Victorian and Edwardian Fashion: A Photographic Survey. New York: Dover, 1981.

Gillet, Thomas. Fashion: A Didactic Sketch. Oxford: Munday and Slatter, 1819.

Gore, Mrs. (Catherine Frances). Mothers and Daughters. 3 vols. Philadelphia: E. L. Carey \& A. Hart: 1834.

Gore, Mrs. (Catherine Frances). Sketches of English Characters. 2 vols. London: Richard Bentley, 1848.

Gore, Mrs. (Catherine Frances). The Woman of the World. London: Henry Colburn, 1838.

"Grand Ball at the Opera." The Court Journal 423 (3 June 1837): 337.

Gravil, Richard. Reading Bleak House. Penrith: HEB Humanities E-Books, 2012.

Habermas, Jürgen. The Structural Transformation of Public Sphere. Trans. Thomas Burger with Frederick Lawrence. Cambridge, MA: MIT P, 1991.

Hack, Daniel. The Material Interests of the Victorian Novel. U of Virginia P, 2005.

Harvey, John. Men in Black. U of Chicago P, 1995.

Hazlitt, William. Selected Writings. Oxford World's Classics, 1998.

Hinton, David. Hunger Mountain. Boston and London: Shambhala, 2012.

Hook, Theodore. Sayings and Doings. London: Henry Colburn, 1836.

Hughes, Linda and Michael Lund. The Victorian Serial. 1991. U of Virginia P, 2015.

"Influence of Example in the Fashionable World, The." The Court Journal 205 (30 Mar. 1833): 213.

Jaffe, Audrey. Vanishing Point: Dickens, Narrative and the Subject of Omniscience. Berkeley: U of California $\mathrm{P}, 1991$.

Jaffe, Audrey. The Victorian Novel Dreams of the Real: Conventions and Ideology. Oxford UP, 2016.

John, Juliet. Ed. Dickens and Mass Culture. Oxford UP, 2012.

John, Juliet. Ed. Dickens and Modernity. D. S. Brewer, 2012.

Jordan, John O. Supposing Bleak House. U of Virginia P, 2011.

Kuchta, David. The Three-Piece Suit and Modern Masculinity. Berkeley: U of California P, 2002.

"La Mode." Le Follet 65 (1 Feb. 1852): 1-4; 66 (1 Mar. 1852): 1-4.

Landon, Letitia. Selected Writings. Broadview Literary Texts, 1997.

Law, Graham. Serializing Fiction in the Victorian Press. Palgrave Macmillan, 2000.

Lehmann, Ulrich. Tigersprung: Fashion in Modernity. Cambridge: MIT, 2000.

Lipovestky, Gilles. The Empire of Fashion: Dressing Modern Democracy. Trans. Catherine Porter. Princeton UP, 1994. 
Mackenzie, Hazel and Ben Winyard. Charles Dickens and the Mid-Victorian Press. U of Buckingham P, 2014.

McClintock, Anne. Imperial Leather: Race, Gender and Sexuality in the Colonial Conquest. New York: Routledge, 1995.

McCracken, Grant. Culture and Consumption: New Approaches to the Symbolic Character of Consumer Goods and Activities. 2 vols. Bloomington: Indiana UP, 1988.

Mckee, Patricia. Reading Constellations: Urban Modernity in Victorian Fiction. Oxford UP, 2014.

McKendrick, Neil et al. The Birth of a Consumer Society: The Commercialization of Eighteenth-Century England. Bloomington: Indiana UP, 1982.

Miller, Andrew H. Burdens of Perfection: On Ethics and Reading in Nineteenth-Century British Literature. Cornell UP, 2008.

Miller, D. A. The Novel and the Police. U of California P, 1988.

Miller, J. Hillis. The Disappearance of God. Harvard UP, 1963.

Milne, William Charles. "The Chinese Adam.” Household Words 256 (17 Feb. 1855): 67-68.

The Morning Chronicle. 14090 (2 July 1814).

"Omnipotence of Fashion, The." The Court Journal 1 (2 May 1829): 2-3.

O' Toole, Sean. Habit in the English Novel, 1850-1900: Lived Environments, Practices of the Self. Palgrave Macmillan, 2013.

Perrot, Philipe. Fashioning the Bourgeoisie: A History of Clothing in the Nineteenth Century. Princeton UP, 1994.

"Philosophy of Fashion, The." The New Monthly Magazine 7.28 (1837): 238-44.

Piggott, Gillian. Nineteenth Century: Dickens and Benjamin: Moments of Revelation, Fragments of Modernity. Ashgate, 2012.

Pigott, Harriet. The Private Correspondence of a Woman of Fashion. London: Henry Colburn and Richard Bentley, 1832.

Pückler-Muskau, German Prince (Hermann, Furst von). Tour in England, Ireland, and France in the Years 1826,1827, 1828 and 1829; with Remarks on the Manners and Customs of the Inhabitants, and Anecdotes of Distinguished Public Characters. 1832. New and revised edition. Zurich VIII: Massie Publishing Co. Ltd, 1940.

Pykett, Lyn. Critical Issues: Charles Dickens. Palgrave, 2002.

"Rambles in Turnbridge Wells." The Ladies' Monthly Museum (1 Dec. 1828): 301-6.

"Remarks on the Progressive Improvement in Fashion and Dress." La Belle Assemblée; or, Bell's Court and Fashionable Magazine 119 (1 Jan. 1819): 36.

Ribeiro, Aileen. The Art of Dress: Fashion in England and France 1750-1820. Yale UP, 1995.

"Rise and Progress of Fashion, The." The London Liteary Pioneer 106 (22 Apr. 1848): 25-26.

Ryan, Vanessa L. Thinking Without Thinking in the Victorian Novel. Baltimore: John Hopkins UP, 2012.

Rylance, Rick. Victorian Psychology and British Culture 1850-1880. Oxford UP, 2000.

Sala, George A. "Fashion." The Household Words 8.188 (29 Oct. 1853): 193-96.

Scholes, Robert and Robert Kellogg. The Nature of Narrative. Oxford UP, 1966.

Schor, Hilary. Dickens and the Daughter of the House. Cambridge UP, 2000.

"Season, The." The Court Journal 38 (16 Jan. 1830): 33-34.

Sennett, Richard. The Culture of New Capitalism. Yale UP, 2006.

"Shadow Hunting." The Court Journal 93 (5 June 1833): 2-3.

Shannon, Brent. "Refashioning Men: Fashion, Masculinity, and the Cultivation of the Male Consumer in Britain, 1860-1914." Victorian Studies 46.4 (2004): 597-630.

"Sketches from Real Life: No. I." The Court Magazine 4.1 (Jan. 1835): 4-13.

Sloan, Casey. "Possessing Dresses: Fashion and Female Community in The Woman in White." Victorian Literature and Culture 44.4 (2016): 801-16.

Spielmann, M. H. The History of Punch. Cassell \& Company Ltd., 1895.

Steele, Valerie. Fashion and Eroticism. Oxford UP, 1985. 
Steele, Valerie. Fetish: Fashion, Sex and Power. Oxford UP, 1996.

Steinlight, Emily. “Anti-Bleak House: Advertising and the Victorian Novel.” Narrative 14.2 (May 2006): $132-62$.

Stone, Mrs. Chronicles of Fashion. London: Richard Bentley, 1845.

Taylor, Jonathan. Science and Omniscience in Nineteenth-Century Literature. Brighton: Sussex Academic P, 2007.

Thackeray, William. The History of Pendennis. 1848-50. Ed. Peter L. Shillingsburg. New York: Garland, 1991.

Times. (16 Apr. 1853): Col A.

Vann, J. Don. Victorian Novels in Serial. MLA of America, 1985.

"Vicissitudes of a Silver Tea-Pot, The" (signed by T. R.). Court Magazine 8.2 (Feb. 1836): 68-72.

Walkley, Christina. Dressed to Impress 1840-1914. London: Batsford, 1989.

Watt, Ian. The Rise of the Novel. U of California P, 1964.

"Where Is the Fashion." The Court Journal 148 (25 Feb. 1832): 113-14.

Williams, Raymond. The English Novel from Dickens to Lawrence. London: Chatto \& Windus, 1970.

"World of London: Second Series: Part I." Blackwood's Edinburgh Magazine 53.327 (Jan. 1843): 67-83.

Zemka, Sue. Time and the Moment in Victorian Literature and Society. Cambridge UP, 2012. 